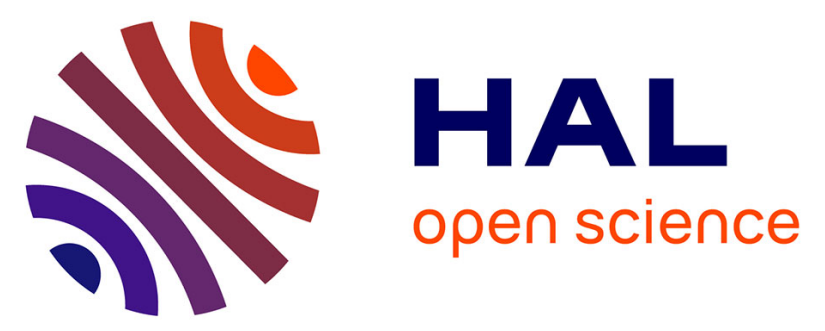

\title{
Early Cretaceous extensional reworking of the Triassic HP-UHP metamorphic orogen in Eastern China
}

\author{
Wei Lin, Wenbin Ji, Michel Faure, Lin Wu, Qiuli Li, Yonghong Shi, Urs \\ Scharer, Fei Wang, Qingchen Wang
}

\section{To cite this version:}

Wei Lin, Wenbin Ji, Michel Faure, Lin Wu, Qiuli Li, et al.. Early Cretaceous extensional reworking of the Triassic HP-UHP metamorphic orogen in Eastern China. Tectonophysics, 2015, 662, pp.256-270. 10.1016/j.tecto.2015.05.028 . insu-01167486

\section{HAL Id: insu-01167486 \\ https://hal-insu.archives-ouvertes.fr/insu-01167486}

Submitted on 24 Jun 2015

HAL is a multi-disciplinary open access archive for the deposit and dissemination of scientific research documents, whether they are published or not. The documents may come from teaching and research institutions in France or abroad, or from public or private research centers.
L'archive ouverte pluridisciplinaire HAL, est destinée au dépôt et à la diffusion de documents scientifiques de niveau recherche, publiés ou non, émanant des établissements d'enseignement et de recherche français ou étrangers, des laboratoires publics ou privés.

\section{다(1)(2)}

Distributed under a Creative Commons Attribution - ShareAlikel 4.0 International 


\section{Accepted Manuscript}

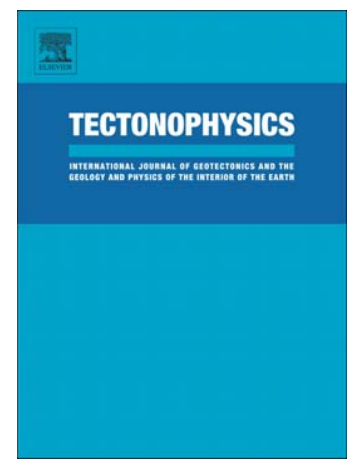

Early Cretaceous extensional reworking of the Triassic HP-UHP metamorphic orogen in Eastern China

Wei Lin, Wenbin Ji, Michel Faure, Lin Wu, Qiuli Li, Yonghong Shi, Urs Scharer, Fei Wang, Qingchen Wang

PII:

S0040-1951(15)00302-9

DOI:

doi: $10.1016 /$ j.tecto.2015.05.028

Reference: $\quad$ TECTO 126651

To appear in: $\quad$ Tectonophysics

Received date: 16 December 2014

Revised date: 22 May 2015

Accepted date: $\quad 24$ May 2015

Please cite this article as: Lin, Wei, Ji, Wenbin, Faure, Michel, Wu, Lin, Li, Qiuli, Shi, Yonghong, Scharer, Urs, Wang, Fei, Wang, Qingchen, Early Cretaceous extensional reworking of the Triassic HP-UHP metamorphic orogen in Eastern China, Tectonophysics (2015), doi: 10.1016/j.tecto.2015.05.028

This is a PDF file of an unedited manuscript that has been accepted for publication. As a service to our customers we are providing this early version of the manuscript. The manuscript will undergo copyediting, typesetting, and review of the resulting proof before it is published in its final form. Please note that during the production process errors may be discovered which could affect the content, and all legal disclaimers that apply to the journal pertain. 


\title{
Early Cretaceous extensional reworking of the Triassic HP-UHP metamorphic orogen in Eastern China
}

Wei Lin ${ }^{\mathrm{a}^{*}}$, Wenbin Ji ${ }^{\mathrm{a}}$, Michel Faure ${ }^{\mathrm{b}}$, Lin $\mathrm{Wu}^{\mathrm{a}}$, Qiuli $\mathrm{Li}^{\mathrm{a}}$, Yonghong Shi ${ }^{\mathrm{c}}$, Urs Scharer ${ }^{\mathrm{d}}$, Fei Wang ${ }^{\mathrm{a}, \mathrm{e}}$, and Qingchen Wang ${ }^{\mathrm{a}}$

${ }^{a}$ State Key Laboratory of Lithospheric Evolution, Institute of Geology and Geophysics, Chinese Academy of Sciences, Beijing 100029, China

b ISTO, Université d'Orléans, UMR 7327, 45071 Orléans Cedex 2, France

${ }^{\mathrm{c}}$ Department of Geology, School of Resource and Environment Engineering, Hefei

University of Technology, China

d Géochronologie, Géosciences Azur CNRS UMR 6526, Université Nice-Sophia Antipolis, parc Valrose, F-06108 Nice, France

${ }^{\mathrm{e}}$ CAS Center for Excellence in Tibetan Plateau Earth Sciences, Beijing 100029, China

Corresponding author. Tel.: +861082 998546; fax: +861062010846.

E-mail address: linwei@ mail.iggcas.ac.cn (W. Lin).

\begin{abstract}
Corresponding to the Early Mesozoic continental subduction between the North China

Block (NCB) and the South China Block (SCB), the Tongbaishan-Hong'an-

Dabieshan-Sulu massifs are famous for their HP-UHP metamorphism. More than $50 \%$ of
\end{abstract}


the HP-UHP Orogenic Belt was significantly reworked by Early Cretaceous extensional tectonics. This Early Cretaceous event with a fast cooling period, at 130-120 Ma, superimposed on the Early Mesozoic HP-UHP orogenic belt and intensively changed the architecture of this orogen. Each individual segment documents different Early Cretaceous extensional structures, namely the central Tongbaishan domain is a metamorphic core complex (MCC) represented by an A-type non-cylindrical antiform; the central Dabieshan domain is a typical Cordilleran-type migmatite-cored MCC; the Southern Sulu UHP domain is a "wedge-shaped" structure exhumed by a simple detachment fault. These late stage extensional structures expose the previous HP-UHP orogenic belt as fragments along the NCB-SCB boundary. The geodynamic setting of this Early Cretaceous extensional tectonics along the HP-UHP orogen is a part of a $1000 \mathrm{~km}$-scale crustal extension belt that is widespread in eastern Eurasia continent from Trans-Baikal to the central part of SCB. Convective erosion or delamination of the mantle lithosphere might be considered as a possible mechanism for mantle removal.

Keywords: Early Cretaceous, extensional structures, Late Triassic, HP-UHP orogen, superimposed orogens, Tongbaishan-Dabieshan-Sulu massifs, Eastern China

\section{Introduction and geological setting}

Superimposed orogens are common in mountain belts. For example, in Europe,

Cenozoic orogens (Alps, Pyrenees) overlapped upon a Variscan basement; in Asia,

Cenozoic Tianshan orogen developed upon a Late Paleozoic one (Tapponnier and Molnar, 
1979; Handy et al. 1999), or the Tertiary Red river-Ailaoshan belt overprinted the Triassic Song Chay-Song Ma belt (Leloup et al., 1995; Faure et al., 2013). The polyorogenic tectonic events associated with multiple deformation phases raise difficulties for structural analysis, and may be misleading in understanding the tectonic evolution of a given area.

In eastern China, the Mesozoic is the most important period responsible for the present tectonic framework. The Triassic convergence between the North China, South China, and Indochina blocks resulted in the formation of the Tongbaishan-Dabieshan-Sulu, the Jinshajiang-North Vietnam, and the Southwest China orogens (Fig. 1X; Hacker et al., 1998, 2009; Faure et al., 1999, 2013 and references therein). Several Late Mesozoic geological features, such as fold and thrust in the Yinshan-Yanshan belt of the north part of NCB, non-rigid continental blocks rotation, crustal-scale ductile extension, widespread volcanism, synsedimentary tectonics, syntectonic plutonism, and strike-slip faults are recognized in eastern China, both in North China Block (NCB) and South China Block (SCB) (Xu et al., 1987; Davis et al., 1996, 2001; Ratschbacher et al., 2000; Ren et al., 2002; Lin et al., 2003, 2013; Wu et al., 2005; Li et al., 2012a).

The HP-UHP orogen of eastern China, situated between the NCB and SCB contains the world's largest HP-UHP metamorphic terrane. From west to east, this orogenic belt consists of the Tongbaishan, Hong'an, Dabieshan, and Sulu massifs (Fig. 1). 
They provide an opportunity to understand the subduction and exhumation processes of these HP-UHP metamorphic rocks (Hacker et al., 2000; Ratschbacher et al., 2000; Zheng et al., 2012 and references therein). Previous workers have already noted that Early Cretaceous extensional structures overprinted the pre-existing HP-UHP orogen in several domains, especially in the central Dabieshan area (Wang et al., 1998, 2011; Ratschbacher et al., 2000 and references therein), from the view of the entire orogenic belt, it was considered that all these mountains belong to the HP-UHP belt and that the Cretaceous event was represented by intensive emplacement of magmatic rocks coupled with crustal reheating and uplifting, and extensional structures were controlled by transtensional strain field as far-field collisions and Pacific subduction (Wang et al., 1998; Faure et al., 1999; Hacker et al., 2000; Ratschbacher et al., 2000; Webb et al., 2001; He et al., 2011). Even the Early Cretaceous geochronological results get from ductilely deformed rocks often accounted for the link between tectonics and crustal heating due to extensive magma emplacement (Faure et al., 1999; Zheng, 2008; Li et al., 2013). In this paper, we argue that the present architecture of the Triassic HP-UHP orogen is largely (more than 50\% of exposed surface) the consequence of the Cretaceous tectonic reworking coeval with crustal anatexis. Individual segment of the orogen documents different Early Cretaceous extensional structures: the central Tongbaishan massif is a metamorphic core complex (MCC) represented by an A-type non-cylindrical antiform; the central Dabieshan massif is a hundreds of kilometers orogen-scale MCC with a perfect detachment normal fault; 
the Southern Sulu UHP massif is a "wedge-shaped" structure exhumed by a single detachment fault.

\section{Late Mesozoic extensional tectonics in the Tongbaishan-Dabieshan-Sulu HP-UHP} orogenic belt

The superimposition of the Cretaceous deformation on the Triassic HP-UHP belt was suggested early by previous studies. For example, in Dabieshan, Wang et al. (1998) advocated for the first time an Early Cretaceous ESE-directed extrusion from the view of structural analysis. On the basis of geochronology, Ratschbacher et al. (2000) and Wang et al. (2011) emphasized the significance of Cretaceous exhumation and unroofing processes by an asymmetric Cordilleran-type extensional complex. Recently, in Tongbaishan, a Cretaceous extensional complex was recognized in agreement with the previous interpretation of eastward tectonic extrusion (Cui et al., 2012; Wang et al., 2003; Webb et al., 2001). Most of the research was concentrated on the extensional structures observed independently in each segment (Ratschbacher et al., 2000; Webb et al., 2001). However, a systematic view of the Cretaceous structural overprint on the entire HP-UHP belt was not yet available.

\subsection{The central Tongbaishan domain}


The Tongbaishan massif, a remnant of the north-subducted SCB, is well known for its HP eclogite-facies metamorphism (Liu et al., 2010). Structurally, it is a composite massif comprising an Early Paleozoic orogen (Qingling group in Fig. 1) and a Late Paleozoic-Early Mesozoic orogen (Flysch type sediment and HP eclogite units in Fig. 1) in the north and south, respectively (Xu et al., 2000; Webb et al., 2001; Liu et al., 2010, 2012). The southern HP orogen consists of felsic gneiss, micaschist, quartzite and marble with numerous eclogite, garnet amphibolite lenses, and several large metagabbro blocks (Liu et al., 2010; Figs. 1, 2a and 2b). In the central part of the entire massif, the central Tongbaishan domain is occupied by a NW-SE trending, long and narrow dome consisting of tonalitic gneiss, gneissic migmatite, amphibolite, marble, and metapelite re-crystallized under amphibolite metamorphism, which separates the HP unit into northern and southern parts (Figs. 1 and 2b). Previous work considered that the central Tongbaishan domain exposed Precambrian basement (Kröner et al., 1993). A Late Triassic metamorphic core complex or antiform structure formed by an extensional process following the Triassic HP metamorphism or attributed to the top-to-the-N ductile shearing were suggested also (Huang et al., 2006). Recently, an Early Cretaceous kilometer-scale strike-slip faults related to compression or extension tectonic setting was assumed to accommodate an eastward extrusion and/or subsequent uplift of the central Tongbaishan domain (Webb et al., 2001; Wang et al., 2003; Cui et al., 2012). Furthermore, a thermal event coeval with sinistral or dextral-transtensional shearing was also proposed (Zhai et al., 1998; Liu et al., 2010). 
In the HP units of the Tongbaishan massif, our field observations reveal a NE-SW mineral stretching lineation (Triassic lineation arrows in Fig. 1) with top-to-the-NE shearing as shown by various shear sense indicators (Figs. 1 and $2 \mathrm{~b}$ ). This pre-Cretaceous deformation can be observed in most units except the central Tongbaishan domain. In map view, the central Tongbaishan domain presents an elliptical shape of ca. $120 \times 10 \sim 20$ $\mathrm{km}^{2}$ with a NW-SE striking long axis (Figs. 1-TB). In the central Tongbaishan domain, a subhorizontal or slightly SE-dipping foliation is developed in the core of this long and narrow dome (Figs. 1-TB, 2a and 2b). In several places, NW-SE striking L-tectonites commonly develop along the axial plane of this antiform (Fig. 3a). Along the NE and SW boundaries of the central Tongbaishan domain, a 0.1 to $1 \mathrm{~km}$-thick mylonitic zones with sub-vertical or high-angle dipping foliation separates the amphibolite-facies metamorphic rocks of the central domain from the HP units (Fig. 2b). Regardless of their locations, whatever on the boundaries or in the middle part of this central domain, the foliation bears a NW-SE trending mineral and stretching lineation with a top-to-the-NW kinematics (Figs. 1-TBS and 3b). These geometry and kinematics show that the central Tongbaishan domain was an A-type non-cylindrical dome opened to the southeast.

\subsection{The central Dabieshan domain}

The Dabieshan massif received a great attention due to the Triassic HP-UHP metamorphism with coesite and micro-diamond inclusions (Fig. 1; Xu et al., 1992; Hacker et al., 2000 and references therein). The central Dabieshan domain predominantly 
consists of granitoids, orthogneisses, migmatites, metasediments with subordinate garnet-bearing amphibolites, eclogites, granulites and ultramafic rocks (Liu et al., 2011 and references therein). Large volumes of this domain underwent granulite to amphibolite facies metamorphism, accompanied by diffuse partial melting of felsic lithologies. The nature of the central Dabieshan domain was previously considered as i) a magmatic complex intruded over a 10-Myr interval between 137 and $126 \mathrm{Ma}$, which accommodated $\sim 100 \%$ N-S stretching of the pre-existing collisional architecture (Hacker et al., 1998); ii) a Triassic or Cretaceous extensive dome (Faure et al., 1999; Suo et al., 2001; Wang et al., 1998); iii) a Cretaceous Cordilleran-type MCC bounded by the Xiaotian-Mozitan detachment fault (XM in Fig. 1; Ratschbacher et al., 2000; Wang et al., 2011a); iv) a part of the subducted Yangtze continental plate that experienced HP or UHP metamorphism (Tsai and Liou, 2000; Lin et al., 2007); v) an extension of the Yangtze basement that was unaffected by UHP metamorphism (Bryant et al., 2004); vi) a Triassic high-temperature UHP unit (Zheng, 2008; Liu et al., 2011); vii) a multistage anatexis of ultrahigh-pressure metamorphic rocks in the continental collision zone (Chen et al., 2015).

The brittle Shang-Ma (SM), brittle Xiaotian-Mozitan (XM) and ductile Shuihou-Wuhe (SW) faults define the western, northern and southeastern boundaries of the central Dabieshan domain, respectively (Fig. 1). Previous work and our systematic measurement of foliation, lineation, and fold axis suggests that the architecture of the Dabieshan is an orogen-scale dome (Wang et al., 1998; Faure et al. 1999; Ratschbacher et al., 2000; Suo et al., 2001; Wang et al., 2011a). 
The N20-30 ${ }^{\circ}$ E striking brittle Shang-Ma fault and constitutes the boundary fault of the Late Cretaceous-Cenozoic basin (1)in Figs. 1) and Hong'an massif to the west (Fig. 1, 2c). The progressive tilt of the red beds suggests that the faulting controlled the sedimentary infill of the basin. The brittle normal fault characterized by down-dip slickenlines and cataclased migmatites overprints a ductile mylonitic zone. The mylonitic foliation dominantly dips at $15-30^{\circ}$ to the NW, along W-E to NW-SE trending striation or lineation, kinematic indicators such as sheared felsic lenses and sigma-type feldspar porphyroclasts indicate a normal motion of the Shang-Ma fault zone with the western side moving downward (Fig. 1-DBS; Fig. 3c). The transition time from ductile to brittle deformation of the Shang-Ma fault was constrained at 126-119 Ma (Wang et al., 2008).

Similar to the Shang-Ma fault, the WNW-ESE trending Xiaotian-Mozitan fault (XM in Fig. 1) is the northern boundary of the central Dabieshan domain. As mentioned by Ratschbacher et al. (2000) and Faure et al. (2003), the Xiaotian-Mozitan fault exhibits brittle and ductile structures also (Fig. 1). The ductile deformation mainly overprinted the migmatite of the central Dabieshan complex. The brittle event is shown by anastomosing striated lenses with an average $\mathrm{N} 50^{\circ} \mathrm{E}$ down-dip slickenlines with the north side moving downward (Faure et al., 2003). The ductile one was indicated by mylonitic foliation generally dips at $20-45^{\circ}$ to the NE or NEE, where bears a conspicuous NW-SE trending stretching lineation and a top-to-the-NW sense of shear (Hacker et al., 1998; Faure et al., 1999; Ratschbacher et al., 2000; Wang et al., 2011a). The hornblende and biotite 
${ }^{40} \mathrm{Ar} /{ }^{39} \mathrm{Ar}$ ages from the mylonitic rocks of the Xiaotian-Mozitan fault document the Early Cretaceous activity (between 142 and $121 \mathrm{Ma}$ (Hou et al., 2007; Wang et al., 2011a).

As a contact between the central Dabieshan domain and the HP-UHP units, the Shuihou-Wuhe fault (SW in Fig. 1) is less well defined, since it is not a sharp boundary as the Shang-Ma fault and the Xiaotian-Mozitan fault, and there is no Cretaceous basin developed along this boundary. Along the southeast boundary of the central Dabieshan domain, a mylonitic zone is well developed not only in the migmatite of central unit, but also in the UHP rocks (Shi et al., 2014). Previous studies interpreted this mylonitic zone as: i) a deep-seated thrust (Okay et al., 1993); ii) the top boundary of UHP rocks (Wang et al., 1995); iii) a normal shear and faulting, locally with cataclastic breccias and transpressive sinistral shear zone (Ratschbacher et al., 2000); iv) a top-to-the-WNW shear zone (Wang e al., 2011). In fact, along this shear zone, the monzogranitic gneisses, tonalite, and paragneiss were deformed by ductile fabric and formed a series of shear zones with lower or moderate angle dipping SE foliation (Fig. 1-DBS; Shi et al., 2014). Mica, K-feldspar and quartz aggregates constitute a conspicuous NW-SE trending lineation. A top-to-the-NW shearing deformation was observed (Hacker et al., 2000; Faure et al., 2003; Wang et al., 2011a). The hornblende and biotite ${ }^{40} \mathrm{Ar} /{ }^{39} \mathrm{Ar}$ datings from the metamorphic rocks and a weakly deformed tonalite near the Shuihou-Wuhe fault yielded 130-124 Ma ages (Ratschbacher et al., 2000).

The westward prolongation of the Shuihou-Wuhe fault was devoid of any study yet. According to our detailed field observations, the Xishui shear zone (XS in Fig. 1) was 
defined as the southern or southwestern boundary of central Dabieshan domain (Wang et al., 1998; Faure et al., 2003; Liu et al., 2011). This shear zone is mainly developed in the UHP-free gneiss unit (Fig.1). Previous researchers interpreted this mylonitic zone as a dextral strike-slip fault (Wang et al., 1998). Unlike typical strike-slip shear zone with vertical or sub-vertical foliation, our field investigation shows that the Xishui shear zone have commonly a flat-lying foliation. Moreover, the preferred orientations of quartz-feldspar aggregates, recrystallized trails around porphyroblast, epidote, biotite and minor amphibole define a well-marked NW-SE trending mineral and stretching lineation (Fig. 1). As the dominant microstructure in this shear zone, the NW-SE trending lineation keeps a subhorizontal dip even when foliation is moderately tilted. All the kinematic indicators show a top-to-the-NW sense of shear (Fig. 3d; Hacker et al., 2000; Faure et al., 2003). Due to lack of geochronological constraint on this high-strain deformation zone, a mylonitic sample (DS349) was collected and analyzed by ${ }^{40} \mathrm{Ar} /{ }^{39} \mathrm{Ar}$ dating to reveal the deformation age (Fig. 1).

\subsection{The southern Sulu massif}

In the southern part of the Sulu HP-UHP orogen, the NE-SW striking Wulian fault is a NW-dipping high-angle brittle normal fault that superimposes upon a low-angle WNW-dipping ductile shear zone with mylonitic and ultramylonitic fabrics and separates the HP-UHP units of southern Sulu (SSL) massif from the marble, amphibolite, and paragneiss (called the Wulian Group, Faure et al., 2003) and the sedimentary rocks of the 
Early Cretaceous Jiaolai basin to the south and north, respectively (Figs. 1 and 2d).

Moreover, pebbles of the gneiss, amphibolite, pelitic schist, and undeformed granite are preserved in the uppermost part of the Early Cretaceous conglomerate (Guo and Sun, 1985; Shi et al., 2003). These sedimentological features and the tilting of the beds towards this brittle fault suggest that normal faulting controlled the sedimentary infill of the basin. Up to now, however, pebbles of eclogites are not the Jiaolai basin (Guo and Sun, 1985; Shi et al., 2003).

The Wulian fault was previously interpreted as: i) a suture zone between NCB and SCB (Yin and Nie, 1993; Leech and Webb, 2013 and references therein); ii) a Late Triassic detachment fault that exhumed the HP-UHP rocks (Faure et al., 2001); iii) an Early Cretaceous detachment fault related to a MCC (Lin et al., 2013; Ni et al., 2013); or iv) the boundary fault between the NCB and SCB reactivated in the Early Cretaceous as a top-to-the-W extensional detachment fault as a part of the Yantai-Qingdao-Wulian (Webb et al., 2006). However, most of the authors considered that the present the architecture of the SSL relates to the Late Triassic HP-UHP orogeny (Faure et al., 2003; Xu et al., 2006; Leech et al., 2006; Hacker et al., 2009; Leech and Webb, 2013).

The SSL is famous for its large area exposure of HP-UHP metamorphism (Ye et al., 2000; Wang et al., 2014a). Geometrically, the architecture of SSL is a stack of tectonometamorphic units (Figs. 1 and 2d). The southern and uppermost unit, well exposed along the seacoast near Lianyungang, is formed by ortho- and paragneiss, and volcanic-sedimentary rocks (SDBGMR, 1991). These rocks experienced a high-pressure 
metamorphism. Lithologically, the UHP Unit is similar to the HP one. It consists of orthogneiss, paragneiss, quartzite, marble, and meter to hectometer sized blocks of mafic and ultramafic rocks. In the SSL, the NE-SW trending foliation, dipping to the WNW and ESE, constitutes an asymmetric antiform (Fig. 2d; Faure et al., 2001, 2003; Xu et al., 2006). This foliation exhibits a conspicuous NW-SE (rarely E-W) mineral and stretching lineation (Fig. 1). Along this lineation,the kinematic indicators are top-to-the-NW or W (Fig. 3e, f; Faure et al., 2001, 2003; Xu et al., 2006; Leech et al., 2006; Webb et al., 2006; Hacker et al., 2009).

\section{New geochronological constraints of the Late Mesozoic extensional tectonics}

Along the HP-UHP orogenic belt between NCB and SCB, three major Early

Cretaceous extensional massifs have been recognized. Samples for geochronological study were collected in the detachment faults and core of the extensional massifs.

Minerals such as zircon, titanite, rutile, biotite and muscovite were carefully checked to match the requirements for a thermochronological study.

\subsection{Analytical Procedures}

\section{Zircon and rutile SIMS $U-P b$ dating}

Zircon and rutile were separated from samples using standard density and magnetic separation techniques. Measurements of $\mathrm{U}, \mathrm{Th}$ and $\mathrm{Pb}$ isotopes were conducted using a Cameca IMS 1280 large-radius SIMS at the Institute of Geology and Geophysics, Chinese Academy of Sciences (IGGCAS) in Beijing. Zircon grains, together with 
standard Plešovice and Qinghu zircons were mounted in epoxy mounts that were then polished to section the crystals in half for analysis. All zircons were photographed in transmitted and reflected light and in cathodoluminescence (CL) in order to reveal their internal structures. The mount was vacuum-coated with high-purity gold for SIMS analyses. U-Th- $\mathrm{Pb}$ ratios and absolute abundances were determined relative to the standard zircon Plešovice (Sláma et al., 2008). Analytical procedures are the same as those described by Li et al. (2009). Correction of common lead was made by measuring ${ }^{204} \mathrm{~Pb}$. Uncertainties on individual analyses in data tables are reported at a $1 \sigma$ level; mean ages for pooled $\mathrm{U} / \mathrm{Pb}($ and $\mathrm{Pb} / \mathrm{Pb}$ ) analyses are quoted with $95 \%$ confidence interval. Data reduction was carried out using the Isoplot program (Ludwig, 2001). The analytical data are listed in Table 1.

Rutile crystals were mounted in a transparent epoxy together with the in-house reference material DXK rutile ( 18 ppm U, 1793 $\pm 3 \mathrm{Ma}$, Li et al, 2003), and JDX rutile $\left(\sim 6 \mathrm{ppm} \mathrm{U},{ }^{207} \mathrm{~Pb} /{ }^{206} \mathrm{~Pb}\right.$ age $=521 \mathrm{Ma},{ }^{206} \mathrm{~Pb} /{ }^{238} \mathrm{U}$ age $=500-520 \mathrm{Ma}$, Li et al., 2011). The mount was well polished to expose the fresh interior of the crystals. After thorough cleaning, the mount was vacuum-coated with high-purity gold prior to ion probe analysis. Rutile U-Pb ratios were calibrated again DXK rutile standard (DXK, Li et al., 2003) following the procedure described by Li et al. (2011). An uncertainty of 3\% (1 RSD) for ${ }^{206} \mathrm{~Pb} /{ }^{238} \mathrm{U}$ measurements of the standard rutiles was propagated to the unknowns. Uncertainties on individual analyses in data tables are reported at a $1 \sigma$ level. For individual age calculation, ${ }^{207} \mathrm{~Pb}$-based common $\mathrm{Pb}$ correction was used (Williams, 
1998; Li et al., 2012b). The final results were based on Tera-Wasserburg Plot using the common-Pb uncorrected data. The analytical data are listed in Table 2.

\section{Titanite $\mathrm{U}-\mathrm{Pb}$ dating}

After selection of the individual grains, and abrasion with pyrite (Krogh 1982), the titanites were washed in $\mathrm{HNO}_{3} 7.5 \mathrm{~N}$ for 1 hour at about $80^{\circ} \mathrm{C}$ and then $\mathrm{H}_{2} \mathrm{O}$ in the same conditions, followed by drying in double distilled acetone. After addition of the mixed ${ }^{205} \mathrm{~Pb}_{-}{ }^{233} \mathrm{U}_{-}{ }^{235} \mathrm{U}$ spike to the dry grains, they were dissolved with HF 54\% in PFA Savilex beakers on the hot plate at $130{ }^{\circ} \mathrm{C}$ during 20 hours. Evaporation of the $\mathrm{HF}$ was followed by dissolution in $\mathrm{HCl} 6 \mathrm{~N}$ at $120{ }^{\circ} \mathrm{C}$, to bake the fluorides at $120{ }^{\circ} \mathrm{C}$ for 2 hours. The dried sample was then taken up in $\mathrm{HCl} 3 \mathrm{~N}$ and then introduced on the anion exchange raisin (AG X8 200-400 mesh). Isotope measurements were performed on a Thomson 206c instrument using a secondary electron multiplier at the Université Nice-Sophia Antipolis, France. $\mathrm{Pb}$ and $\mathrm{U}$ were loaded together on an outgased single Re filament with $\mathrm{H}_{3} \mathrm{PO}_{4}$, silica-gel, measured subsequently at $1350-1450{ }^{\circ} \mathrm{C}$ and $1450-1550{ }^{\circ} \mathrm{C}$, respectively. Mass discrimination was regularly controlled with the NBS $981 \mathrm{~Pb}$ standard yielding a value of $0.1 \pm 0.05 \% / \mathrm{amu}$, for which all data are corrected. The weight of titanite fractions analyzed ranges between 0.1256 and $0.4507 \mathrm{mg}$, for which two different volumes of anionic resin had to be chosen to guarantee stable ion emission. Corresponding blanks and further information on the analytical procedure are given in the footnotes of Table 3. 


\section{Mica Ar-Ar dating}

Aliquots of micas of mylonites formed along the detachment faults were wrapped separately in aluminum foil to form wafers, and stacked in quartz vial. The samples were irradiated at the H8 position of 49-2 Nuclear Reactor (China Institute of Atomic Energy, Beijing) for $36 \mathrm{~h}$. High resolution ${ }^{40} \mathrm{Ar} /{ }^{39} \mathrm{Ar}$ measurements were performed by using mass-spectrometer MM5400 at ${ }^{40} \mathrm{Ar} /{ }^{39} \mathrm{Ar}$ laboratory of IGGCAS, following the procedures described in Wang et al. (2006). Samples were heated stepwise with a double vacuum resistance furnace. The released gas was purified with $\mathrm{Zr}$-Al getters. After corrections for mass discrimination, system blanks, radiometric interference, ${ }^{40} \mathrm{Ar} /{ }^{39} \mathrm{Ar}$ ages were calculated according to ${ }^{40} \mathrm{Ar} *{ }^{39} \mathrm{Ar}_{\mathrm{K}}$ ratios and $\mathbf{J}$ value obtained by analyses of the monitors, as well as the decay constant. The parameters for calculation are selected as described in Wang et al. (2014b). The data were processed using ArArCALC software (Koppers et al., 2000), and the apparent ages are reported at $2 \sigma$ uncertainties at the $95 \%$ confidence level. The ${ }^{40} \mathrm{Ar} /{ }^{39} \mathrm{Ar}$ analytical data are listed in Table 4.

\subsection{Results related Cretaceous extension tectonic}

Zircon $\mathrm{U}-\mathrm{Pb}$ dating o a migmatitic leucosome (sample HO-37)

A migmatitc leucosome (sample HO37), was taken from the central Tongbaishan domain in the footwall of the detachment fault. Twenty-three grains of zircon were analyzed by SIMS, and yield a ${ }^{206} \mathrm{~Pb} /{ }^{238} \mathrm{U}$ concordia age of $132.8 \pm 0.9 \mathrm{Ma}$ (Fig. 4a, Table 1). This age is slightly younger than the previous data for the central domain of the 
massif (Cui et al., 2012). CL images and Th/U ratios (Fig. 4b) of the dated zircon grains suggest that they are hydrothermal in origin. We interpret this Early Cretaceous age as representing the migmatization time during the partial melting of middle crust.

Titanite $\mathrm{U}-\mathrm{Pb}$ analytical results for the HO-37 migmatitic leucosome

Table 3 lists the individual results obtained for 8 different titanite size fractions, composed between 4 and 20 grains. Four of the fractions are abraded grains, whereas the remaining was simply washed in $\mathrm{HNO}_{3}$ after individual selection. The population is of excellent crystallographic quality, with the dominant mass of grains being developed as euhedral, transparent, inclusion and crack-free crystals varying in pleochroism between yellow and yellow-brown. Initial common $\mathrm{Pb}$ in the titanites is high $\left({ }^{206} \mathrm{~Pb} /{ }^{204} \mathrm{~Pb}\right.$ ratios around 40) with the correction for such $\mathrm{Pb}$ inducing relatively large errors (see ellipses in Fig. 4c) lying at $1.5-2.0 \%$ for ${ }^{206} \mathrm{~Pb} / 238 \mathrm{U}$, and $2.3-3.5 \%$ for ${ }^{207} \mathrm{~Pb} / 235 \mathrm{U}$ having correlation coefficients between 0.50 and 0.65 .

The titanites show surprisingly variable $U$ ranging between 31 and 385 ppm, with corresponding radiogenic $\mathrm{Pb}$ between 0.85 and $10 \mathrm{ppm}$. On the other hand, initial common $\mathrm{Pb}$ is relatively constant as illustrated be the small range of $206 \mathrm{~Pb} / 204 \mathrm{~Pb}$ measured. Plotted in the concordia diagram four of the fractions are identically concordant (Fig. 1a), a further fraction overlaps in error with three of these dates, whereas another analysis also plots concordantly but with about $2 \%$ younger ages. Two of the fractions reveal the presence of inherited older radiogenic $\mathrm{Pb}$ (Fig. 4c) which was most 
likely incorporated during crystal growth, together with common $\mathrm{Pb}$. This is suggested by the absence of older cores, such as often seen in zircon, in contrast to titanite, for which inheritance could never be related to over-growth of inherited relic crystals (cores). The presence of such inherited radiogenic $\mathrm{Pb}$ is not surprising given the fact that the granite is essentially crustal derived. The time of titanite crystallization, i.e. solidification of the granitic magma can be derived from the four identically concordant fractions yielding an age of $120.0 \pm 1.1(2 \sigma)$ Ma. The slightly younger apparent ages of the two other concordant fractions (analyses \# 2 and 4) can be ascribed to very minor Pb loss, most likely from the outermost parts of the grains as suggested by the fact that these two fractions were not abraded, in contrast to three of the identically concordant grains, and the grains showing inheritance. Concerning the age of inherited $\mathrm{Pb}$, minimum ages of about 0.5 and $1.4 \mathrm{Ga}$ can be deduced $\left({ }^{207} \mathrm{~Pb} / 206 \mathrm{~Pb}\right.$ ratios, Table 2$)$.

\section{${ }^{40} \mathrm{Ar}{ }^{39} \mathrm{Ar}$ dating results}

Biotite sample JS349, separated from mylonitic gneiss of the XS shear zone of southwest central Dabieshan domain (Fig. 1), yield a ${ }^{40} \mathrm{Ar} /{ }^{39} \mathrm{Ar}$ plateau age of $125.8 \pm 0.9$ Ma (Fig. 4d). This age is interpreted as representing cooling during activity of the XS shear zone. This is consistent with results reported by Ratschbacher et al. (2000) near the Shuihou-Wuhe fault, who obtained biotite ${ }^{40} \mathrm{Ar}-{ }^{39} \mathrm{Ar}$ ages yielded 126.4 $\pm 1.2 \mathrm{Ma}$, and $124 \pm 2 \mathrm{Ma}$.

Muscovite sample LU36, taken from a micaceous mylonite along footwall of the Wulian fault (Fig. 1), gives a ${ }^{40} \mathrm{Ar} /{ }^{39} \mathrm{Ar}$ plateau age of $127.1 \pm 0.7 \mathrm{Ma}$ (Fig. 4e). This age 
is much younger than the previous dating, who obtained a micaceous ultramylonite (SU30), yielded a weighted mean age of $145.3 \pm 6.6 \mathrm{Ma}$; but to be compared with white mica, which take from a synkinematic pegmatite vein resulted in a weighted mean age of 128.2 \pm 0.7 Ma about several kilometers W or SW along the Wulian fault (Webb et al., 2006). So these Early Cretaceous ages are better to be interpreted as representing cooling during activity of the Wulian detachment fault.

Rutile U-Pb dating of the eclogite from the central Dabieshan MCC and SSL

Rutile in sample LT-3, separated from eclogite in the Central Dabieshan MCC. A total of twenty-six analyses were performed on 26 rutile crystals. Most rutile crystals are about $150 \mu \mathrm{m}$ in diameter, with the largest up to $300 \mu \mathrm{m}$. The measured $\mathrm{U}$ contents range from 12 to $31 \mathrm{ppm}$ (Table 2). On the Tera-Wasserburg plot linear regression of the data points $(\mathrm{MSWD}=1.5)$ gives a lower intercept age of $129.6 \pm 2.8 \mathrm{Ma}$ (Fig. 4f).

Eclogite LU34 was taken from the southern Sulu massif, and ten valid analyses on 10 rutile grains in this simple were acquired. Their $\mathrm{U}$ content varies from 0.11 to 0.59 ppm (Table 2). Regression of the data points on the Tera-Wasserburg plot (MSWD = 0.75) gives a lower intercept age of $130.2 \pm 9.4 \mathrm{Ma}$ (Fig. 4g).

\section{Discussion}

\subsection{The central Tongbaishan: an extension or an extrusion structure?}


Along the NE and SW boundaries of the central Tongbaishan domain, Early

Cretaceous sinistral and dextral shear zones developed, respectively (Ratschbacher et al., 2000; Webb et al., 2001). Combined with the eastward continuation of the Huwan detachment zone in Hong' an massif and Xiaotian-Mozitang fault in Dabieshan massif, these opposed kinematics were interpreted as a late deformation episode, which involved primarily strike-slip motion and little or no tectonic exhumation, related to the eastward extrusion driven by the Jurassic-Cretaceous collision of the Lhasa block with Eurasia (Webb et al., 2001), or an eastward crustal extrusion, and clockwise rotation event (Wang et al., 2003). However, a detailed survey shows that from the center to the NE and SW margins of the central Tongbaishan, the dip angle of the foliation increases progressively from shallow to vertical, which argues for a late folding stagethat inflected the early foliation. When correcting the fold to its original geometry with a shallow inclined foliation, the contrasting shear senses on the NE and SW margins after the folding could be reconciled into a single top-to-the NW shearing during the formation of foliation and lineation. This architecture shows that the central Tongbaishan domain was an A-type non-cylindrical antiform like a triangle open to the southeast. We interpret this geometry and related kinematics as a detachment normal fault related to the central Tongbaishan MCC (Figs. 1 and 2a). This new interpretation is similar to the A-type non-cylindrical dome or of the Aegean domain where the 3D thermomechanical modeling confirmed an extensional setting instead of a transpression or strike-slip one (Le Pourhiet et al., 2012). 
Combined with the previous ${ }^{40} \mathrm{Ar} /{ }^{39} \mathrm{Ar}$ dating (Cui et al., 2012), our $132.8 \pm 0.9$ Ma SIMS zircon U-Pb and 120.1 \pm 1 Ma titanite $\mathrm{U}-\mathrm{Pb}$ ages indicate that the central Tongbaishan domain was a extensional structure which was formed during the Early Cretaceous, experienced a fast cooling during 130-120 Ma and a subsequent slow cooling up to $90 \mathrm{Ma}$ (Figs. 4a, b, c, and 5; Tables 1 and 2; Xu and Wang, 2010). Similar to the other Early Cretaceous extensional structures of eastern Eurasia, such as the South Liaodong Peninsula, Linglong, Yiwulushan, and Yunmengshan detachment faults, Yagan-Onch Hayrhan, and Hohhot, from East to West (Lin et al., 2013 and references therein), the central Tongbaishan is interpreted as an extensional structure with a major detachment fault around the central migmatitic domain (Fig. 1a). This NW-SE trending A-type non-cylindrical antiform reworked the previous HP belt and split it into the NE and SW parts (Fig. 1).

\subsection{The central Dabieshan: an Cordilleran-type asymmetric MCC}

As the major part of the Triassic HP-UHP orogenic belt of eastern China, the central Dabieshan domain was previously considered as a Triassic or Cretaceous extensional dome or a magmatic complex with a detachment normal fault located along the Xiaotian-Mozitan fault (Wang et al., 1998, 2011; Faure et al., 1999; Ratschbacher et al., 2000). The significant role of the SM fault was always ignored in the proposed models for the origin of this migmatite dome, such as the later extrusion model (Wang et al., 1998), the rolling hinge-isostatic rebound model (Ratschbacher et al., 2000), the 
orogen-parallel extension of the ductile lithosphere (Wang et al., 2011a). Based on structural analyses and new chronological results, we redefine this ENE-WSW long axis gneissic migmatite dome as a cordilleran-type Early Cretaceous asymmetric MCC with an arched detachment normal fault developed during 145 120 Ma with a rapid cooling between 130-120 Ma (Figs. 2c and 5). Low-angle NE and NW dipping mylonitic foliation, along the XM and SM faults respectively, constitute the northern-northwestern detachment fault of the MCC (Fig. 1). The related NW-SE stretching lineation indicates the extension direction that accommodated the progressive exhumation of the footwall from deep to shallow depths. The ${ }^{40} \mathrm{Ar} /{ }^{39} \mathrm{Ar}$ datings along the Shuihou-Wuhe (SW) and Xishui (XS) shear zones, which were previously viewed as Late Triassic detachment faults between the UHP units and central Dabieshan orthogneiss unit (Wang et al., 1995), show that the ductile deformation occurred around $126 \mathrm{Ma}$ (Fig. 4d, Table 4). SW and SE dipping low-angle mylonitic foliation along these faults constitutes the southern and southeastern parts of the same detachment fault along the margin of the MCC (Figs. 1 and 2c). The regular domal architecture of the MCC, and the consistent top-to-the-NW kinematics of the detachment faults indicate that they initiated as a uniform, flat-lying shear zone and became progressively arched due to the isostatic equilibration during exhumation (Figs. 2c, and 3c, d). At the southeast of this gneissic migmatite dome, the HP-UHP terrane with a SE or S dipping foliation and consistent NW-SE mineral and stretching lineation, form a supra-detachment litho-tectonic stack of metamorphic units (Faure et al., 1999). In spite of similar top-to-the-NW sense of shear, the Cretaceous 
kinematics associated with the Cretaceous detachment normal fault, must be distinguished from the Triassic deformation. In the supra-detachment units, the various metamorphic facies and lack of early Cretaceous cooling allow us to separate two tectonic stages in the Dabieshan orogenic belt (Fig. 1). The central Dabieshan gneissic migmatite dome was considered as a high-temperature UHP unit due to the occurrence of eclogite relicts in the migmatite that indicated higher temperature than in the South Dabieshan domain (Zheng, 2008; Liu et al., 2011). Our rutile U-Pb dating in these eclogites relicts shows a narrow age span around $129 \mathrm{Ma}$ (Fig. 4f; Table 2), indicating that the central Dabieshan MCC developed at the expense of the previous UHP unit situated in the middle to lower crust during the late Triassic. This view is at variance to that of partial melting of the Yangtze crust unaffected by the UHP metamorphism considered as already exhumed to the surface during the late Triassic (Bryant et al., 2004; Chen et al., 2015 and references therein). Because of this late extensional event, the UHP eclogite was exhumed from middle-lower crust to the surface during the early Cretaceous. This result complies well with the previous work on the granite-gneiss exhumation processes (Ratschbacher et al., 2000).

The Early Cretaceous migmatization and magmatism coeval with the Dabieshan MCC exhumation belong to the same tectonic-thermal event. The formation of this hundred kilometers orogen-scale MCC and the related supradetachment basins have largely reworked the Early Mesozoic HP-UHP orogenic framework and separated the HP-UHP units into two parts (Fig. 1). Alike for the central Tongbaishan MCC, this large 
extension structure corresponds to the decoupled surface between the pre-exhumated HP-UHP slabs and reunited middle-lower crust of eastern China (Fig. 2b; Hacker et al., 1998, Webb et al., 2001; Lin et al., 2013).

\subsection{Early Cretaceous extensional structure in the Sulu UHP belt: a rolling hinge}

In SSL, most of the geochronological data get by various methods on different minerals from eclogite and host-gneiss show a Triassic HP-UHP metamorphic and deformation event (Chen et al., 1992; Li et al., 1994; Faure et al., 2003; Xu et al., 2006; Leech et al., 2006; Webb et al., 2006; Hacker et al., 2006, 2009; Liu et al., 2008, 2009; Schmidt et al., 2011; Leech and Webb, 2013). Some ${ }^{40} \mathrm{Ar} /{ }^{39} \mathrm{Ar}$ analyses from the granite, gneiss, pegmatite, mafic dyke indicated a significant Cretaceous magmatism (Wallis et al., 1999; Lin et al., 2005; Hacker et al., 2009). The late Mesozoic ages derived from L-S tectonites were mentioned unapparent (Faure et al., 2003; Webb et al., 2006; Xu et al., 2006), and related to a resetting due to the widespread Cretaceous igneous activity (Faure et al., 2003; Hacker et al., 2009). Alternatively, an exhumation limited to a few kilometers because of the top-to-the-W detachment was also suggested (Webb et al., 2006). Similar to the Central Dabieshan MCC, our new muscovite ${ }^{40} \mathrm{Ar} /{ }^{39} \mathrm{Ar}$ dating along the Wulian ductile shear zone shows that the ductile deformation occurred around $127 \mathrm{Ma}(\mathrm{Fig} .4 \mathrm{e}$, Table 4). More to the south, in the Taohang area (Fig. 1), SIMS U-Pb dating of rutile from eclogite shows a lower intercept age at 130.2 \pm 9.4 Ma (Fig. 4g). Combined with previous ${ }^{40} \mathrm{Ar} /{ }^{39} \mathrm{Ar}$ dating of $\mathrm{K}$-feldspar and muscovite, these data argue for a fast cooling 
rate of about $40-50^{\circ} \mathrm{C} / \mathrm{m}$.y. along the Wulian fault during the Early Cretaceous (Lin et al., 2005; Figs.1and 5). Biotite, muscovite, plagioclase, K-feldspar, and hornblende ${ }^{40} \mathrm{Ar} /{ }^{39} \mathrm{Ar}$ datings, from Wulian fault to Lianyungang area, show that most of the SSL recorded this Early Cretaceous fast cooling event (Fig. 5). The closure temperatures of the individual geochronometers indicate an isothermal decrease from NW to SE, spatially associated with the Wulian detachment (Fig. 2d). The different areas of the SSL, such as Wulian shear zone, Taohang, Yangkou, Rizhao, and Lianyungang areas, the cooling paths document a fast exhumation process from SE to NW during the Early Cretaceous (Figs. 1, $2 \mathrm{~d}$ and 5). This means that the SSL was a Cretaceous "wedge-shaped" extensional structure bounded by a detachment fault instead of a suture zone, magmatism and related reheating zone or a MCC (Yin and Nie, 1993; Faure et al., 2003; Hacker et al., 2009; Lin et al., 2013). South of Lianyungang, the ${ }^{40} \mathrm{Ar} /{ }^{39} \mathrm{Ar}$ K-feldspar closure temperature line indicates that the HP unit of Sulu belt was buried at $6 \sim 10 \mathrm{~km}$ before the Early Cretaceous extension (Figs. 1 and 2d). Thus, the Wulian detachment fault would be better considered as the result action of a rolling ring that facilitated the tilting of the SSL, leading to exhumation of the HP-UHP rocks to the surface from a depth more than $10 \mathrm{~km}$ (Fig. 2d). In contrast to the central Dabieshan MCC, the Wulian detachment fault was not subsequently arched. From the view of the area occupied by the SSL, the Early Cretaceous extension exhumed more than $90 \%$ of the South Sulu HP-UHP orogenic belt (Fig. 1). This conclusion agrees well with the sedimentary record around the SSL, either in the Jiaolai basin or the Lingshan island at the NW and SE, respectively. The 
terrigeneous rocks of these basins are devoid of any Triassic metamorphic material derived from the Sulu UHP metamorphic belt (Xie et al., 2012; Wang et al., 2014c).

\subsection{Early Cretaceous event: continental-scalet reheating or extensional tectonics?}

In the HP-UHP orogenic belt of Eastern China, this Early Cretaceous event was documented by widespread emplacement of magmatic rocks associated with crustal heating, limited extension, and uplifting (Hacker et al., 2000, 2009; Ratschbacher et al., 2000; Webb et al., 2001; Wang et al., 2011a; He et al., 2011; Leech and Webb, 2013 and reference therein). The Early Cretaceous geochronological results from the tectonites of the HP-UHP orogenic belt are often regarded to be perturbated by heating related to magma emplacement (Faure et al., 1999; Zheng, 2008; Hacker et al., 2009; Leech and Webb, 2013). Our structural work around the central Tongbaishan, central Dabieshan and SSL indicate that the Early Cretaceous event was an extensional tectonic event characterized by the development of contemporaneous detachment faults. Besides our research area, NW-SE striking extensional structures are quite common in the whole eastern Eurasian continent, such as Trans Baikal-Mongolia-Great Xing'an range, Yinshan-Yanshan range, Eastern China and Korea rage, Eastern Qinling-Dabieshan range and South China block (Fig.1a; Fig. 6; Lin et al., 2013). Thus in our interpretation, the continental scale NW-SE extension accounts for the apparent age of most the ${ }^{40} \mathrm{Ar} /{ }^{39} \mathrm{Ar}$ dating rather than the thermal resetting by the Cretaceous magmatism (Fig.6; Lin et al., 2013). Another hypothesis regarded this Early Cretaceous extensional tectonics along the 
HP-UHP orogen (WNW-ESE) of eastern China as a post-collisional collapse of the Triassic orogen triggered by slab break-off (Okay et al., 1993). However, more than 100 M.y. delay between the Triassic thinning and Cretaceous extensional tectonics makes this interpretation difficult to be considered (Davies and von Blanckenburg, 1995; Yang et al., 2005; He et al., 2011).

In the eastern Eurasian continent, the continental-scale extensional tectonics, characterized by a NW-SE maximum stretching direction and numerous detachment faults, developed in a narrow time span around 130-120 Ma, and a very large area from Trans-Baikal to SCB, over more than 3000 km (Figs. 1a and 6). Unlike the Basin and Range Province in North America where the MCCs are distributed parallel to the Cordilleran orogenic belt, these Early Cretaceous extensional structures of eastern Asia do not exhibit a clear linear pattern, since they sporadically crop out in a wide area of the continent (Fig. 1a). If the extensional tectonics shares the same geodynamic origin, it should not be confined within the HP-UHP orogenic belt of eastern China. Perhaps, NW-directed subduction of the Paleo-Pacific plate which led to back-arc mantle lithosphere removal (convective removal or delamination) with expected hydro-weakening might account for the extensional tectonics involved in large continental area during a short time span of Late Mesozoic (Okay et al., 1993; Lin and Wang, 2006; Windley et al., 2010). A-type non-cylindrical antiform or dome such as central Tongbaishan MCC, B-type cylindrical dome such as central Dabieshan MCC, and a single detachment normal fault such as SSL, correspond to the different styles of the 
middle or upper crust extension of this lithospheric process (Fig. 7). These late stage extensional structures dismembered the pre-existing HP-UHP slices as fragments exposed along the NCB-SCB boundary.

\section{Conclusions}

To sum up, the Early Cretaceous large-scale extensional structures, with a fast cooling period at 130-120 Ma, superimposed on the previous Early Mesozoic HP-UHP orogenic belt, and intensively changed the architecture of this orogen. The Tongbaishan HP massif was separated by a long and narrow, NW-SE striking A-type non-cylindrical antiform, which occupies more than half of this HP segment. The formation of the hundred km-scale Dabieshan MCC and related supradetachment basin separated the HP-UHP massifs into two parts in Hong'an massif and SE Dabieshan HP-UHP domain. In the SSL, the Wulian detachment fault exhumed all the UHP rocks and more than 50\% of the presently exposed HP rocks. This Early Cretaceous extensional tectonic have significantly reconstructed the previous Triassic architecture of the HP-UHP orogen and left it exposed as fragments along the NCB-SCB boundary (Fig. 1). Detail field and laboratory structural analysis, and geochronological assessment allow us to decipher this complex orogenic belt.

\section{References}


Bryant, D. L., Ayers, J. C., Gao, S., Miller, C. F. \& Zhang, H., 2004. Geochemical, age, and isotopic constraints on the location of the Sino-Korean/Yangtze Suture and evolution of the Northern Dabie Complex, east central China. G.S.A. Bulletin 116, 698-717.

Charles, N., Gumiaux, C., Augier, R., Chen, Y., Lin, W., Zhu, R., 2011. Metamorphic Core Complex vs. Synkinematic pluton in continental extension setting: Insights from key structures (Shandong Province, eastern China). J. of Asian Earth Sci. 40, 261-278.

Chen, R.X., Ding, B., Zheng, Y.F., Hu, Z., 2015. Multiple episodes of anatexis in a collisional orogen: Zircon evidence from migmatite in the Dabie orogen. Lithos 212-215, 247-265.

Chen, W.J., Harrison, T., Matthew, M., Heizerler, T., Liu, R., Ma, B., Li, J., 1992. The Cooling History of Melange Zone in North Jiangsu-South Shandong Region: Evidence from Multiple diffusion domain, ${ }^{40} \mathrm{Ar}-{ }^{39} \mathrm{Ar}$ Thermal Geochronology. Acta. Petrol. Sin. 8, 1-17 (in Chinese with English abstract).

Cui, J., Liu, X., Dong, S., Hu, J., 2012. U-Pb and ${ }^{40} \mathrm{Ar} /{ }^{39} \mathrm{Ar}$ geochronology of the Tongbai complex, central China: Implications for Cretaceous exhumation and lateral extrusion of the Tongbai-Dabie HP/UHP terrane. J. of Asian Earth Sci. 47, 155-170.

Daoudene, Y., Gapai,s D., Ledru, P., Cocherie, A., Hocquet, S., Donskaya, T.V., 2009. The Ereendavaa Range (north-eastern Mongolia): an additional argument for Mesozoic extension throughout eastern Asia. Int. J. of Earth Sci. 98, 1381-1393.

Davies, G.A., Qian, X., Zheng, Y., Yu, H., Wang, C., Mao, T.H., Gehrels, G.E., Muhammad, S., Fryxell, J.E., 1996. Mesozoic deformation and plutonism in the Yunmeng Shan: A Chinese metamorphic core complex north of Beijing, China, in: 
Yin, A., Harrison, T.A. (Eds), The Tectonic Evolution of Asia. Cambridge University Press, New York, pp. 253-280.

Davies, J., von Blanckenburg, F., 1995. Slab breakoff: A model of lithosphere detachment and its test in the magmatism and deformation of collisional orogens. Earth Planet. Sci. Lett. 129, 85-102.

Davis, G.A., Darby, B.J., 2010. Early Cretaceous overprinting of the Mesozoic Daqing Shan fold-and-thrust belt by the Hohhot metamorphic core complex, Inner Mongolia, China. Earth Sci. Frontiers 17, 1-20.

Davis. G.A., Zheng, Y., Wang, C., Darby, B.J., Zhang, Ch., Gehrels, G.E., 2001. Mesozoic tectonic evolution of the Yanshan fold and thrust belt, with emphasis on Hebei and Liaoning provinces, northern China, in: Hendrix, M.S., Davis, G.A. (Eds), Paleozoic and Mesozoic Tectonic Evolution of Central Asia: From Continental Assembly to Intracontinental Deformation. Boulder, Colorado, Geol. Soc. of Am. 194, pp. 171-194.

Donskaya, T.V., Windley, B.F., Mazukabzov, A.M., Kröner, A., Sklyarov, E.V., Gladkochub, D.P., Ponomarchuk, V.A., Badarch, G., Reichow, M.K., Hegner, E., 2008. Age and evolution of late Mesozoic metamorphic core complexes in southern Siberia and northern Mongolia. J. of Geol. Soc. of London 165, 405-421.

Faure, M., Lepvrier, C., Van, V. N., Tich, V.V., Lin, W., Chen, Z., 2013. The South China block-Indochina collision: Where, when, and how? J. of Asian Earth Sci. 79, 260-274.

Faure, M., Lin, W., Le Breton, N., 2001. Where is the North China-South China Blocks boundary in Eastern China? Geology 29, 119-122. 
Faure, M., Lin, W., Monié, P., Le Breton, N., Poussineau, S., Panis, D., Deloule, E., 2003. Exhumation tectonics of the ultra high-pressure metamorphic rocks in the Qinling orogen in East China: New petrological-structural-radiometric insights from the Shandong peninsula. Tectonics 22, 1018, doi: 10.1029/2002TC001450.

Faure, M., Lin, W., Shu, L.S., Sun, Y., Schärer, U., 1999. Tectonics of the Dabieshan (eastern China) and possible exhumation mechanism of ultrahigh-pressure rocks. Terra Nova 11, 251-258.

Faure, M., Sun, Y., Shu, L., Monié, P., Charvet, J., 1996. Extensional tectonics within a subduction-type orogen. The case study of the Wugongshan dome (Jiangxi Province, SE China). Tectonophysics 263, 77-108.

Guo, Z., Sun, X. 1985. Discovery of oolitic limestone gravels and Forminifer and Fusulinid fossils in the upper Jurassic on the southern margin of the Jiao-Lai depression, Eastern Shandong and their tectonic significance. Geol. Rev., 31, 179-183 (in Chinese with English abstract).

Hacker, B.R., Ratschbacher, L., Webb, L.E., Ireland, T., Walker, D., Dong, S.W., 1998. $\mathrm{U} / \mathrm{Pb}$ zircon ages constrain the architecture of the ultrahigh-pressure Qinling-Dabie orogen, China. Earth Planet. Sci. Lett. 161, 215-230.

Hacker, B.R., Ratschbacher, L., Webb, L.E., McWilliams, M.O., Ireland, T., Calvert, A., Dong, S.W., Wenk, H.R., Chateigner, D., 2000. Exhumation of ultrahigh-pressure continental crust in east central China: Late Triassic-Early Jurassic tectonic unroofing. J. Geophys. Res. 105(B6), 13339-13364.

Hacker, B.R., Wallis S.R., McWilliams, M.O., Gans P.B., 2009. ${ }^{40} \mathrm{Ar} /{ }^{39} \mathrm{Ar}$ Constraints on the tectonic history and architecture of the ultrahigh-pressure Sulu orogen. J. Metamorph. Geol. 27, 827-844. 
Hacker, B.R., Wallis, S.R., Ratschbacher, L., Grove, M., and Gehrels, G., 2006. High-temperature geochronology constraints on the tectonic history and architecture of the ultrahigh-pressure Dabie-Sulu orogen. Tectonics 25, TC5006; doi: 10.1029/2001JB001129/2005TC001937.

Han, B.F., Zheng, Y.D., Gan, J.W., Chang, Z.S., 2001. The Louzidian normal fault near Chifeng, Inner Mongolia: master fault of a quasi-metamorphic core complex. Int. Geol. Rev. 43, 254-264.

Handy, M.R., Franz, L., Heller, F., Janett, B., Zurbriggen, R., 1999. Multistage accretion and exhumation of the continental crust (Ivrea crustal section, Italy and Switzerland). Tectonics 18, 1154-1177.

He, Y., Li, S., Hoefs, J., Huang, F., Liu, S., Hou Z., 2011. Post-collisional granitoids from the Dabie orogen: New evidence for partial melting of a thickened continental crust. Geochim. Cosmochim. Acta 75, 3815-3838.

Hou, Q., Liu, Q., Li, J., Zhang, H., 2007. Late Mesozoic shear zones and its chronology in the Dabie Mountains, Central China. Chin. J. of Geol. 42, 114- 123 (in Chinese with English abstract).

Huang, S.Y., Xu, B., Wang, C.Q., Zhan, S., Deng, R.J., 2006. Geometry, kinematics and evolution of Tongbai Orogen. Sci. in China Ser. D: Earth Sci. 49, 828-838.

Jaffey, A.H., Flynn, K.F., Glendenin, L.E., Bentley, W.C., Essling, A.M., 1971. Precision measurement of half-lives and specific activities of ${ }^{238} \mathrm{U}$ and ${ }^{235} \mathrm{U}$. Phys. Rev. 4, 1889-1906.

Ji, W., Lin, W., Shi, Y., Wang, Q., Chu, Y., 2011. Structure and evolution of the Early Cretaceous Dabieshan metamorphic core complex. Chin. J. of Geol. 46, 161-180 (in Chinese with English abstract). 
Koppers, P., Staudigel, H., Wijbrans, J.R., 2000. Dating crystalline groundmass separates of altered Cretaceous seamount basalts by the ${ }^{40} \mathrm{Ar} /{ }^{39} \mathrm{Ar}$ incremental heating technique. Chem. Geol. 166, 139-158.

Krogh, T. E., 1982. Improved accuracy of U-Pb zircon ages by the creation of more concordant system using air abrasion technique. Geochim. Cosmochim. Acta 46, 637-649.

Kröner, A., Zhang, G.W., Sun, Y., 1993. Granulites in the Tongbai area, Qinling belt, China: geochemistry, petrology, single zircon geochronology, and implications for the tectonic evolution of eastern Asia. Tectonics 12, 245-255.

Le Pourhiet, L., Huet, B., May, D.A., Labrousse, L., Jolivet, L., 2012. Kinematic interpretation of the 3D shapes of metamorphic core complexes, Geochem. Geophys. Geosyst. 13, Q09002, doi:10.1029/2012GC004271.

Leech, M.L., Webb, L.E., 2013. Is the HP-UHP Hong'an-Dabie-Sulu orogen a piercing point for offset on the Tan-Lu fault? J. Asian Earth Sci. 63, 112-129

Leech, M.L., Webb, L.E., Yang, T., 2006. Diachronous histories for the Dabie-Sulu orogen from high-temperature geochronology, in: Hacker, B.R., McClelland, W.C., Liou, J.G. (Eds.), Ultra high pressure metamorphism: Deep continental subduction. Geol. Soc. of Am. Spec. Pap., 403, pp. 1-22.

Leloup, P.H., Lacassin, R., Tapponnier, P., Schärer, U., Zhong, D., Liu, X., Zhang, L., Ji, S., Trinh, P., 1995. The Ailaoshan-Red River shear zone (Yunnan, china), Tertiary transform boundary of Indochina. Tectonophysics 252, 3-84.

Li, Q.L., Li, S.G., Zheng, Y.-F., Li, H.M., Massonne, H.J., Wang, Q.C., 2003. A high precision $\mathrm{U}-\mathrm{Pb}$ age of metamorphic rutile in coesite-bearing eclogite from the Dabie 
Mountains in central China: a new constraint on the cooling history. Chem. Geol. 200, $255-265$.

Li, Q.L., Li, X.H., Wu, F.Y., Yin, Q.Z., Ye, H.M., Liu, Y., Tang, G.Q., Zhang, C.L., 2012b. In-situ SIMS U-Pb dating of Phanerozoic apatite with low $\mathrm{U}$ and high common Pb. Gond. Res. 21, 745-756.

Li, Q.L., Yang, Y., Shi, Y., Lin, W., 2013. Eclogite rutile U-Pb dating: constraint for formation and evolution of continental collisional orogen. Chin. Sci. Bull. 58, 2279-2284 (in Chinese).

Li, Q.L., Lin W., Su W., Li X.H., Shi Y.H., Liu Y., Tang G.Q. 2011. SIMS U-Pb rutile age of low-temperature eclogites from Southwestern Chinese Tianshan, NW China. Lithos 122, 76-86.

Li, S., Wang, S., Chen, Y., Liu, D., Qiu, J., Zhou, H., Zhang, Z., 1994. Excess argon in phengite from eclogite: evidence from dating of eclogite minerals by $\mathrm{Sm}-\mathrm{Nd}, \mathrm{Rb}-\mathrm{Sr}$ and ${ }^{40} \mathrm{Ar} /{ }^{39} \mathrm{Ar}$ method. Chem. Geol. 112, 343-350.

Li, S., Zhao, G., Dai, L., Liu, X., Zhou, L., Santosh, M., Suo, Y., 2012a. Mesozoic basins in eastern China and their bearing on the deconstruction of the North China Craton. J. Asian Earth Sci. 47, 64-79.

Li, X.H., Liu, Y., Li, Q.L., Guo, C.H., Chamberlain, K.R., 2009. Precise determination of Phanerozoic zircon $\mathrm{Pb} / \mathrm{Pb}$ age by multi-collector SIMS without external standardization. Geochem. Geophys. Geosyst. 10, Q04010, doi:10.1029/2009GC002400. 
Lin, L.H., Wang, P.L., Lo, C.H., Tsai, C.H., Jahn, B.M., 2005. ${ }^{40} \mathrm{Ar}-{ }^{39} \mathrm{Ar}$ thermochronological constraints on the exhumation of ultrahigh-pressure metamorphic rocks in the Sulu Terrane of eastern China. Int.Geol. Rev. 47, 872-886.

Lin, W., Chen, Y., Faure, M., Wang, Q., 2003. Tectonic implications of new Late Cretaceous paleomagnetic constraints from Eastern Liaoning Peninsula, NE China. J. Geophys. Res., 108(B6), EPM5-1 to 5-17.

Lin, W., Enami, M., Faure, M., Scharer, U., Arnaud, N., 2007. Survival of eclogite xenolith in a Cretaceous granite intruding the Central Dabieshan migmatite gneiss dome (Eastern China) and its tectonic implications. Int. J. of Earth Sci. 96, 707-724.

Lin, W., Faure, M., Chen, Y., Ji, W., Wang, F., Wu, L., Charles, N., Wang, J., Wang, Q., 2013. Late Mesozoic compressional to extensional tectonics in the Yiwulüshan massif, NE China and its bearing on the evolution of the Yinshan-Yanshan orogenic belt. Part I: Structural analyses and geochronological constraints. Gondw. Res. 23, 54-77.

Lin, W., Faure, M., Monié, P., Schärer, U., Panis, D., 2008. Mesozoic extensional tectonics in Eastern Asia: The South Liaodong Peninsula Metamorphic Core Complex (NE China). J. of Geol. 116, 134-154.

Lin, W., Faure, M., Monié, P., Schärer, U., Zhang, L., Sun, Y., 2000. Tectonics of SE China, new insights from the Lushan massif (Jiangxi Province). Tectonics 19, 852-871.

Lin, W., Wang, Q., 2006. Late Mesozoic extensional tectonics in North China Block Response to the Lithosphere removal of North China Craton? Bull. de la Soc. Géol. de France 177, 287-294. 
Lin, W., Wang, Q.C., Wang, J., Wang, F., Chu, Y., Chen, K., 2011. Late Mesozoic extensional tectonics of the Liaodong Peninsula massif: response of crust to continental Lithosphere destruction of the North China Craton. Sci. in China (Earth Sci.) $54,843-857$.

Liu, F., Gerdes, A., Zeng, L., Xue, H., 2008. SHRIMP U-Pb dating, trace elements and the Lu-Hf isotope system of coesite-bearing zircon from amphibolite in the SW Sulu UHP terrane, eastern China. Geochim. Cosmochim. Acta 72, 2973-3000.

Liu, F.L., Gerdes, A., Liou, J.G., Liu, P., 2009. Unique coesite-bearing zircon from allanite-bearing gneisses: $\mathrm{U}-\mathrm{Pb}, \mathrm{REE}$ and $\mathrm{Lu}-\mathrm{Hf}$ properties and implications for the evolution of the Sulu UHP terrane, China. Eur. J. Mineral. 21, 1225-1250.

Liu, J., Davis, G., Lin, Z., Wu, F., 2005. The Liaonan metamorphic core complex, southeastern Liaoning Province, North China: A likely contributor to Cretaceous rotation of eastern Liaoning, Korea and contiguous areas. Tectonophysics 407, 65-80.

Liu, X., Li, S.Z., Suo, Y.H., Liu, X.C., Dai, L.M., Santosh, M., 2012. Structural analysis of the northern Tongbai Metamorphic Terranes, Central China: Implications for Paleozoic accretionary process on the southern margin of the North China Craton. J. Asian Earth Sci. 47, 143-154.

Liu, X.C., Jahn, B.M., Cui, J.J., Li, S.Z., Wu, Y.B., Li, X.H., 2010. Triassic retrograded eclogites and Cretaceous gneissic granites in the Tongbai Complex, central China: implications for the architecture of the HP/UHP Tongbai-Dabie-Sulu collision zone. Lithos 119, 211-237.

Liu, Y., Gu, X., Li, S., Hou, Z., Song, B., 2011. Multistage metamorphic events in granulitized eclogites from the North Dabie complex zone, central China: Evidence from zircon $\mathrm{U}-\mathrm{Pb}$ age, trace element and mineral inclusion. Lithos 122, 107-121. 
Ludwig, K.R., 2001. Users Manual for Isoplot/Ex rev. 2.49. Berkeley Geochronology

Centre Special Publication. No. 1a, 56 pp.

Mazukabzov, A.M., Donskaya, T.V., Gladkochub, D.P., Sklyarov, E.V., Ponomarchuk, V.A., Salnikova, E.B., 2006. Structure and age of the metamorphic core complex of the Burgutui ridge (Southwestern Transbaikal region). Doklady Earth Sci. 407, $179-183$.

Mazukabzov, A.M., Gladkochub, D.P., Donskaya, T.V., Sklyarov, E.V., Ripp, G.S., Izbrodin, I.A., Wang, T., Zeng, L.S., 2011. The Selenga Metamorphic Core Complex (Western Transbaikalian Region). Doklady Earth Sci. 440, 1212-1215.

Ni, J., Liu, J., Tang, X., Yang, H., Xia, Z., Guo, Q., 2013. The Wulian Metamorphic Core Complex: A Newly Discovered Metamorphic Core Complex along the Sulu Orogenic Belt, Eastern China. J. of Earth Sci. 24, 297-313 (in Chinese with English abstract).

Okay, A., Sengor, A., Satir, M., 1993. Tectonics of an ultrahigh-pressure metamorphic terrane: the Dabie Shan/Tongbieshan orogen, China. Tectonics 12, 1320-1334.

Ratschbacher, L., Hacker, B.R., Webb, L., McWilliams, M.O., Ireland, T., Dong, S., Calvert, A., Chateigner, D., Wenk, H., 2000. Exhumation of ultrahigh- pressure continental crust in east central China: Cretaceous and Cenozoic unroofing and the Tan-Lu fault. J. Geophys. Res. 105, 13303-13338.

Ren, J., Kensaku, T., Li, S., Zhang, J., 2002. Late Mesozoic and Cenozoic rifting and its dynamic setting in Eastern China and adjacent areas. Tectonophysics 344, 175-205.

SDBGMR, 1991. Shandong Bureau of Geology and Mineral Resources, Regional Geology of Shandong Province, 639 pp., Geol. Publ., Beijing. 
Schmidt, A., Mezger, K., O’Brien, P.J., 2011. The time of eclogite formation in the ultrahigh pressure rocks of the Sulu terrane: constraints from Lu-Hf garnet geochronology. Lithos 125, 743-756.

Shi, W., Zhang, Y.Q., Dong, S., Wu, L., Du, L., 2003. Tectonic deformation and formation and evolution of the Jiao-Lai basin, Shandong: A case study of a deformation analysis of the Wangshi and Dasheng Group. Geol. Bull. of China 22, 325-334 (in Chinese with English abstract).

Shi, Y., Lin, W., Ji, W., Wang, Q., 2014. The architecture of the HP-UHP Dabie massif: new insights from geothermobarometry of eclogites, and implication for the continental exhumation processes. J. Asian Earth Sci. 86, 38-58.

Sláma, J., Košler, J., Condon, D.J., Crowley, J.L., Gerdes, A., Hanchar, J.M., Horstwood, M.S.A., Morris, G.A., Nasdala, L., Norberg, N., Schaltegger, U., Schoene, B., Tubrett, M.N., Whitehouse, M.J., 2008. Plešovice zircon - a new natural reference material for $\mathrm{U}-\mathrm{Pb}$ and $\mathrm{Hf}$ isotopic microanalysis. Chem. Geol. 249, 1-35.

Stacey, J.S., Kramer, J.D., 1975. Approximation of terrestrial lead isotope evolution by a two stage model. Earth Planet Sci. Lett. 26, 207-221.

Steiger, R.H., Jäger, E., 1977. Subcomission on Geochronology, Convention on the use of decay constants in geo- and cosmochronology. Earth Planet. Sci. Lett. 36, 359-362.

Suo, S.T., Zhong, Z.Q., You, Z.D., Zhang, Z.M., 2001. Post-collisional ductile extensional tectonic framework in the UHP and HP metamorphic belts in the Dabie-Sulu region, China. Acta Geol. Sinica 75, 151-160 (in Chinese with English abstract). 
Tapponnier, P., Molnar, P., 1979. Active faulting and Cenozoic tectonics of the Tien Shan, Mongolia and Baykao regions. J. Geophys. Res. 84, 3425-3459.

Tsai, Ch., Liou, J.G., 2000. Eclogite-facies relics and inferred ultrahigh-pressure metamorphism in the North Dabie Complex, central-eastern China. Am. Mineral. 85, $1-8$.

Wallis, S.R., Enami, M., and Banno, S., 1999. The Sulu UHP terrane-A review of the petrology and structural geology. Int. Geol. Rev. 41, 906-920.

Wang ,Y., Li, H., 2008. Initial Formation and Mesozoic Tectonic Exhumation of an Intracontinental Tectonic Belt of the Northern Part of the Taihang Mountain Belt, Eastern Asia. J. of Geol. 116, 155-172.

Wang, E.Q., Meng, Q.R., Burchfiel, B.C., Zhang, G.W., 2003. Mesozoic large-scale lateral extrusion, rotation and uplift of the Tongbai-Dabie Shan belt in east China. Geology 31, 307-310.

Wang, F., He, H.Y., Zhu, R.X., Sang, H.Q., Wang, Y.L., Yang, L.K., 2006. Intercalibration of internatioal and domestic ${ }^{40} \mathrm{Ar} /{ }^{39} \mathrm{Ar}$ dating standards. Sci. China-Earth Sci. 49, 461-470.

Wang, J., Chang, S.C., Lu, H.B., Zhang, H.C., 2014c. Detrital zircon U-Pb age constraints on Cretaceous sedimentary rocks of Lingshan Island and implications for tectonic evolution of Eastern Shandong, North China. J. Asian Earth Sci. 96, $27-45$.

Wang, F., Wang, Q., Lin, W., Wu, L., Shi, W., Feng H., Zhu R., 2014b. ${ }^{40} \mathrm{Ar} /{ }^{39} \mathrm{Ar}$ geochronology of the North China and Yangtze Cratons: New constraints on 
Mesozoic cooling and cratonic destruction under East Asia. J. Geophys. Res. Solid Earth 119, 3700-3721.

Wang, L., Kusky, T., Polat, A., Wang, S., Jiang, X., Zong, K.,Wang, J., Deng, H., Fu, J., 2014a. Partial melting of deeply subducted eclogite from the Sulu orogen in China. Nature, DOI: 10.1038/ncomms6604.

Wang, P., Wang, G., Liu, C., Wang, A., Ye, R., 2008. Zircon U-Pb Geochronology of the Shangma Fault, Dabie: Constraints on the Transformation from Ducti le to Brittle Deformation, and Its Significance to the Tectonic Evolution of Dabie Orogenic Belt. Ear. Sci.-J. of China Univ. of Geosci. 174-182 (in Chinese with English abstract).

Wang, Q., Liu, X., Maruyama, S., Cong, B., 1995. Top boundary of the Dabie UHPM rocks, Central China. J. of Southeast Asia Earth Sci. 11, 195-300.

Wang, T., Guo, L., Zheng, Y.D., Donskaya, T.V., Gladkochub, D., Zeng, L., Li, J., Wang, Y., Mazukabzov, A., 2012. Timing and processes of late Mesozoic mid-lower-crustal extension in continental NE Asia and implications for the tectonic setting of the destruction of the North China Craton, Mainly constrained by zircon U-Pb ages from metamorphic core complexes. Lithos 154, 315-345.

Wang, X.D., Neubauer, F., Genser, J., Yang, W.R., 1998. The Dabie UHP unit, central China: A Cretaceous extensional allochthon superposed on a Triassic orogen. Terra Nova 10, 260-267.

Wang, Y., Zhou, L., Li, J., 2011b. Intracontinental superimposed tectonics-A case study in the Western Hills of Beijing, eastern China. G.S.A. Bulletin 123, 1033-1055. 
Wang, Y.S., Xiang, B.W., Zhu, G., Jiang, D.Z., 2011a. Structural and geochronological evidence for Early Cretaceous orogen-parallel extension of the ductile lithosphere in the northern Dabie orogenic belt, East China. J. Struct. Geol. 33, 362-380.

Wang, Z.G., Zhang, L.X., 1999. Metamorphic core complex in Xiongershan and the advances in prospecting. Geol. Expl. for Non-ferrous Metals 8, 388-392 (in Chinese with English abstract).

Webb, L.E., Graham, S.A., Johnson, C.L., Badarch, G., Hendrix, S., 1999. Occurrence, age, and implications of the Yagan-Onch Hayrhan metamorphic core complex, southern Mongolia. Geology 27, 143-146.

Webb, L.E., Leech, M.L., Yang, T.N., 2006. ${ }^{40} \mathrm{Ar} /{ }^{39} \mathrm{Ar}$ Thermochronology of the Sulu Terrane: Late Triassic Exhumation of High- and Ultrahigh-Pressure Rocks and Implications for Mesozoic Tectonics in East Asia, in: Hacker, B.R., McClelland, W.C., Liou, J.G. (Eds.), Ultra high pressure metamorphism: Deep continental subduction, Geol. Soc. of Am. Spec. Pap., 403, 77-92.

Webb, L.E., Ratschbacher, L., Hacker, B.R., Dong, S., 2001. Kinematics of exhumation of high- and ultrahigh-pressure rocks in the Hong' an and Tongbai Shan of the Qinling-Dabie collisional orogen, eastern China, in: Hendrix, M.S., Davis, G.A. (Eds), Paleozoic and Mesozoic Tectonic Evolution of Central Asia: From Continental Assembly to Intracontinental Deformation. Boulder, Colorado, Geol. Soc. of Am., 194, pp. 231-245.

Williams, I.S., 1998. U-Th-Pb geochronology by ion microprobe, in: McKibben, M.A., Shanks III, W.C., Ridley, W.I (Eds.), Applications of microanalytical techniques to understanding mineralizing processes. Rev. in Economic Geol. 7, 1-35. 
Windley, B., Maruyama, S., Xiao, W., 2010. Delamination/Thinning of Sub-continental Lithospheric mantle under Eastern China: The role of water and multiple subduction. Am. J. of Sci. 310, 1250-1293

Wu, F.Y., Han, R.H., Yang, J.H., Wilde, S.A., Zhai, M.G., Park, S.C., 2007. Initial constraints on the timing of granitic magmatism in North Korea using U-Pb zircon geochronology. Chem. Geol. 238, 232-248.

Wu, F.Y., Lin, J.Q, Wilde, S.A., Zhang, X.O., Yang, J.H., 2005. Nature and significance of the Early Cretaceous giant igneous event in eastern China. Earth Planet. Sci. Lett. 233, 103-119.

Xie, S., Wu, Y., Zhang, Z., Qin, Y., Liu, X., Wang, H., Qin, Z., Liu, Q., Yang, S., 2012. $\mathrm{U}-\mathrm{Pb}$ ages and trace elements of detrital zircons from Early Cretaceous sedimentary rocks in the Jiaolai Basin, north margin of the Sulu UHP terrane: provenances and tectonic implications. Lithos 154, 346-360.

Xu, B., Grove, M., Wang, C.Q., Zhang, L.F., Liu, S.W., 2000. ${ }^{40} \mathrm{Ar} /{ }^{39} \mathrm{Ar}$ thermochronology from the northwestern Dabie Shan: constraints on the evolution of Qinling-Dabie orogenic belt, east-central China. Tectonophysics 322, 279-301.

Xu, G., Wang, E.Q., 2010. The uplift mechanism of Tongbai complex in Mesozoic and its coupling relationship with Nanyang Basin. Chin. J. of Geol. 45, 626-652 (in Chinese with English abstract).

Xu, J., Zhu, G., Tong, W., Cui, K., Liu, Q., 1987. Formation and evolution of the Tancheng-Lujiang wrench fault system: a major shear system to the northwest Pacific Ocean. Tectonophysics 134, 273-310. 
Xu, S.T., Okay, A., Ji, S., Sengör, A.M.C., Su, W., Liu, Y., Jiang, L., 1992. Diamond from Dabie Shan metamorphic rocks and its implication for tectonic setting. Science 256, 80-82.

Xu, Z., Zeng, L., Liu, F., Yang, J., Zhang, Z., McWilliams, M., Liou, J.G., 2006. Polyphase subduction and exhumation of the Sulu high-pressure- ultrahighpressure metamorphic terrane, in: Hacker, B.R., McClelland, W.C., Liou, J.G. (Eds.), Ultra high pressure metamorphism: Deep continental subduction. Geol. Soc. of Am. Spec. Pap., 403, pp. 93-113.

Yang, J.H., Chung, S.L., Wilde, S.A., Wu, F.Y., Chu, M., Lo, Ch., Fan, H., 2005. Petrogenesis of post orogenic syenites in the Sulu Orogenic Belt, East China: geochronology, geochemical and Nd-Sr isotopic evidence. Chem. Geol. 214, 99-125.

Yang, W.C., Yang, W.Y., Chen, Z., 2004. Interpretation of 3D seismic reflection data in the Chinese Continental Scientific Drilling site. Acta. Petrol. Sin. 20, 127-137 (in Chinese with English abstract).

Ye, K., Cong, B., Ye, D., 2000. The possible subduction of continental material to depths greater than $200 \mathrm{~km}$. Nature 407, 734-736.

Yin, A., Nie, S., 1993. An indentation model for the north and south China collision and the development of the Tan-Lu and Honam fault systems, eastern Asia. Tectonics $12,801-813$.

Yin, A., Nie, S., 1996. A Phanerozoic palinspastic reconstruction of China and its neighboring regions, in: Yin, A., Harrison, T.A. (Eds), The Tectonic Evolution of Asia. Cambridge University Press, New York, pp. 442-485. 
Zhai, X.M., Day, H.W., Hacker, B.R., You, Z.D., 1998. Paleozoic metamorphism in the Qinling orogen, Tongbai Mountains, central China. Geology 26, 371-374.

Zhang, J.J., Zheng, Y., Shi, Q., Yu, X., Zhang, Q., 1997. The Xiaoqinling detachment fault and metamorphic core complex of China: structure, kinematics, strain and evolution. Proceedings of the 30th Int. Geol. Congress 14, 158-172.

Zhang, X.D., Yu, Q., Chen, F.J., Wang, X.W., 2000. Structural characteristics, origin and evolution of metamorphic core complex in Central Basement Uplift and Xujiaweizi Faulted Depression in Songliao Basin, Northeast China. Earth Sci. Frontiers 7, 411-419 (in Chinese with English abstract).

Zhao, H.B., Mo, X.X., Xu, S.M., Li, S.L., Ma, B.Y., 2007. Composition and evolution of the Xinkailing metamorphic core complex in Heilongjiang province. Chinese J. of Geol. 42,176-188.

Zheng, Y.F., 2008. A perspective view on ultrahigh-pressure metamorphism and continental collision in the Dabie-Sulu orogenic belt. Chin. Sci. Bull. 53, 3081-3104.

Zheng, Y.F., Zhang, L.F., McClelland, W.C., 2012. Processes in continental collision zones: Preface. Lithos 136-139, 1-9.

Zhu, G., Xie, C., Chen, W., Xiang, B., Hu, Z., 2010. Evolution of the Hongzhen metamorphic core complex: Evidence for Early Cretaceous extension in the eastern Yangtze craton, eastern China. G.S.A. Bulletin 122, 506-516.

Zorin, Y.A., 1999. Geodynamics of the western part of the Mongolia-Okhotsk collisional belt, Trans-Baikal region (Russia) and Mongolia. Tectonophysics 306, 33-56. 


\section{Acknowledgements}

This work has been supported by NSFC (41225009, 41472193), the Project of Major State Special Research on Petroleum (2011ZX05008-001), and the "Strategic Priority Research Program" of the Chinese Academy of Science (XDB03020203). The first author (W. Lin) is grateful to Brian Windley for discussing the UHP orogenic belt of China during his stay in IGG. We gratefully acknowledge G. Davis and W. Wei for the discussions and enlightening suggestions that helped us to greatly improve the paper.

\section{Figure captions}

Fig. 1. Simplified geological map of the central eastern China high pressure and ultrahigh pressure orogenic belt from Tongbaishan to Sulu massifs. Insert a shows the location of the extensional massifs in the eastern Eurasia continent. Figure modified after Faure et al., (2003), Hacker et al., (2006). TBS, DBS, and SSM are diagrams of structural planar $(\mathrm{P})$ and linear $(\mathrm{L})$ elements of the central Tongbaishan domain, central Dabieshan domain and southern Sulu massif respectively. All diagrams are equiareal Schmidt net, lower hemisphere. NB: Nanyang basin, TB: Tongbaishan massif, HA: Hong'an massif, DB: Dabieshan massif, FD: Feidong massif, ZB: Zhangbaling massif, SSL: southern Sulu massif, NSL: northern Sulu massif, SM: Shangma fault, XM: Xiaotian-Mozitan fault, SW: Shuihou-Wuhefault, XS: Xishui fault, YY:

Yinshan-Yanshan fold and thrust belt, CAOB: Central Asian Orogenic Belt. (1)Late Cretaceous-Cenozoic Macheng-Xinzhou basin, (2)Cretaceous volcanic-clastic Xiaotian basin. 
Fig. 2. Schematic cross sections across the central eastern China polystage orogenic belt. $a$ and $b$. Schematic cross section through the Tongbaishan massif with different direction; c. Schematic cross section through the Dabieshan massif (modified from Ji et al., 2011); d. Reinterpreted seismic profile through the southern Sulu massif after Yang et al.(2004). Different dash line show the closure temperature of different minerals in ${ }^{40} \mathrm{Ar}^{39}{ }^{39} \mathrm{Ar}$ and U-Pb systems, Rut: rutile; Amp: Amphibole; Mus: Muscovite; Bio: Biotite; and Kfs: K-feldspar. Unnoted symbols and captions in the map are the same as in figure 1.

Fig. 3. Field and thin-section (cut parallel to the stretching lineation and perpendicular to the foliation) illustrations of the structures and kinematics related to the Early Cretaceous extensional tectonics. a. L-type tectonites in the central Tongbaishan MCC; b. Top-to-the-NW asymmetric pressure shadow around K-feldspar porphyroblasts and shear band in the central Tongbaishan MCC; c. Asymmetric felsic leucosome in gneissic migmatite indicating a top-to-the-NW shearing in the central Dabieshan MCC; d. Top-to-the-NW asymmetric pressure shadow around a quartz clast in the mylonitic migmatite of Central Dabieshan MCC; e. Sigma-type K-feldspar porphyroclast in ultramylontic orthogneiss, southern Sulu massif; f. Delta-type porphyroclast of zoisite in ultramylontic orthogneiss, southern Sulu massif.

Fig. 4. Geochronological results show the Early Cretaceous extensional tectonics. a and $\mathrm{b}$. zircon SIMS U/Pb dating concordia diagram and cathodomuminescence image with the analysis spots the from the central Tongbaishan MCC; c. U/Pb dating on the 
titanite from the migmatite of the central Tongbaishan MCC; d. ${ }^{40} \mathrm{Ar}-{ }^{39} \mathrm{Ar}$ dating on biotite along the south detachment fault of central Dabieshan MCC; e. ${ }^{40} \mathrm{Ar} /{ }^{39} \mathrm{Ar}$ dating on muscovite along the Wulian detachment fault of southern Sulu massif; f. SIMS U/Pb dating on the rutile from the Luotian eclogite of the central Dabieshan MCC massif; g. $\mathrm{U} / \mathrm{Pb}$ dating on the rutile from the Taohang eclogite of the southern Sulu massif.

Fig. 5. Cooling paths of the central Tongbaishan A-type non-cylindrical antiform, central Dabieshan MCC, and southern Sulu massifs. The cooling path of southern Sulu massif was separated from NW to SE through the Wulian detachment fault, Taohang, Yangkou, Rizhao and Lianyungang areas. Geochronological results from central Tongbaishan: Xu and Wang, 2010; Cui et al., 2012; Webb et al., 2001; Liu et al., 2012 and our works, central Dabieshan: Ratschbacher et al., 2000; Ji et al., 2011 and references therein and our works, southern Sulu massif: Chen et al., 1992; Faure et al., 2003; Lin et al., 2005; Hacker et al., 2009; Schmidt et al., 2011; Leech and Webb, 2013 and references therein, and this work..

Fig. 6. Extensional structures (extensional dome, magmatic domes and detachment faults) and their radiochronological ages in the eastern part of the Eurasian continent. The dashed line indicates the relative probability of the biotite ${ }^{40} \mathrm{Ar} /{ }^{39} \mathrm{Ar}$ dating on the ductile detachment faults. Abbreviations: Trans Baikal-Mogolia-Great Xing'an range: UU (Ulan-Ude (Selenga) MCC, Mazukabzov et al., 2011; Wang et al., 2012), Xk (Xinkailing magmatic dome, Zhao et al., 2007), Yb (Yablonovy MCC, Zorin, 1999), Zg (Zagan MCC, Donskaya et al, 2008), Bb (Buteel-Burgutui MCC, Mazukabzov et al., 
2006; Donskaya et al., 2008); Ed (Ereendavaa MCC, Daoudene et al., 2009); Cb

(Central basement uplift of Songliao basin MCC, Zhang et al., 2000); Nt (Nartyn magmatic dome, Daoudene et al., 2009); Yinshan-Yanshan range (YY): Yg (Yagan-Onch Hayrhan MCC, Webb et al., 1999), Hh (Hohhot MCC, Davis and Darby, 2010), Ym (Yunmengshan MCC, Davis et al., 1996), Xs (Xishan magmatic dome, Wang et al., 2011b), Zjg (Zijingguan magmatic dome, Wang and Li, 2008), Kl (Kalaqin magmatic dome, Han et al., 2001), Yw (Yiwulüshan MCC, Lin et al., 2013); Eastern China and Korea: Np (Nampho magmatic dome, Wu et al., 2007), Gd (Gudaoling magmatic dome, Lin et al., 2011), Ymw (Yimawanshan magmatic dome, Lin et al., 2011), Sl (South Liaodong Peninsula MCC, Yin and Nie, 1996; Liu et al., 2005; Lin et al., 2008), Xy (Xiuyan MCC, Lin et al., 2011), Gjl (Guojialing magmatic dome, Charles et al., 2011), Ll (Linglong detachment fault, Charles et al., 2011), SSL (South Sulu detachment fault, this work); Eastern Qinling-Dabieshan: Xql (Xiaoqinling MCC, Zhang et al., 1997); Xrs (Xiongershan magmatic dome, Wang and Zhang, 1999), Tbs (Tongbaishan MCC, this work), Cdb (Central Dabieshan MCC, this work); South China block: Hz (Hongzhen magmatic dome, Zhu et al., 2010), Ls (Lushan magmatic dome, Lin et al., 2000), Dy (Dayunshan syntectonic granite, Our field survey), and Zf (magmatic dome Zhangfang in Wugongshan massif, Faure et al., 1996). The times of formation of the metamorphic complexes and domes are indicated to reflect the active time of detachment fault. Locations are indicated on figure $1 \mathrm{X}$. 
Fig. 7. A 3D conceptual geodynamic model illustrating the different Early

Cretaceous extensional structures developed in the Eurasian plate. CTD: central

Tongbaishan domain, CDD: central Dabieshan domain, and SSM: southern Sulu massif

\section{Tables}

Table 1. SIMS U-Pb analytical results for zircon of the HO37 migmatite from the central Tongbaishan MCC.

Table 2. SIMS U-Pb analytical results for rutile of the eclogite.

Table 3. U-Pb analytical results for titanite of the HO37 migmatite from the central Tongbaishan MCC.

Table $4 .{ }^{40} \mathrm{Ar} /{ }^{39} \mathrm{Ar}$ analytical results from detachment fault. 


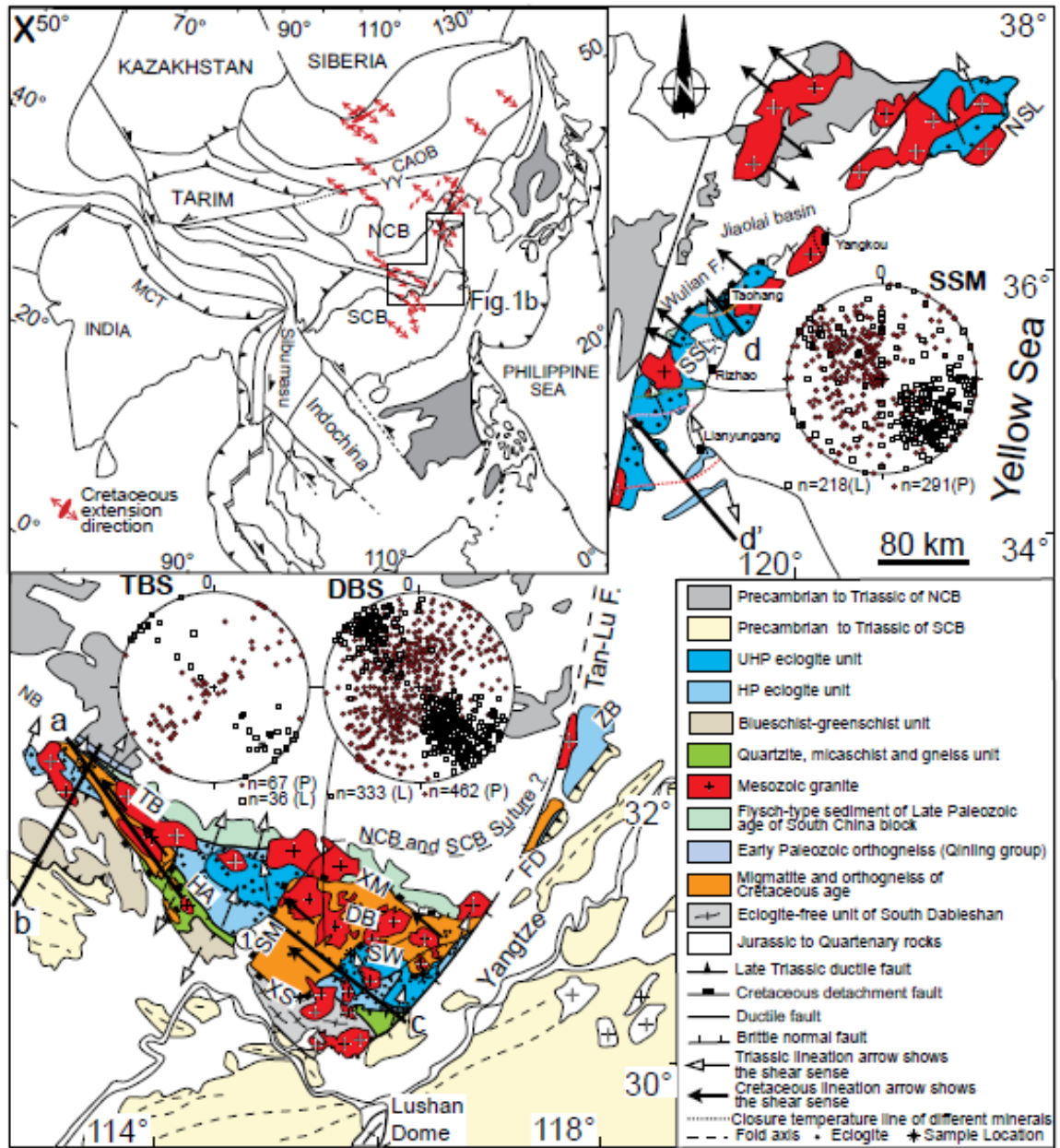

Fig. 1. Simplified geological map of the central eastern China high pressure and ultrahigh pressure orogenic belt from Tongbaishan to Sulu massifs. Insert a shows the location of the extensional massifs in the eastern Eurasia continent. Figure modified after Faure et al., (2003), Hacker et al., (2006). TBS, DBS, and SSM are diagrams of structural planar $(\mathrm{P})$ and linear $(\mathrm{L})$ elements of the central Tongbaishan domain, central Dabieshan domain and southern Sulu massif respectively. All diagrams are equiareal Schmidt net, lower hemisphere. NB: Nanyang basin, TB: Tongbaishan massif, HA: Hong'an massif, DB: Dabieshan massif, FD: Feidong massif, ZB: Zhangbaling massif, SSL: southern Sulu massif, NSL: northem Sulu massif, SM: Shangma fault, XM: Xiaotian-Mozitan fault, SW: Shuihou-Wuhefault, XS: Xishui fault, YY: Yinshan-Yanshan fold and thrust belt, CAOB: Central Asian Orogenic Belt. (1) Late Cretaceous-Cenozoic Macheng-Xinzhou basin, (2) Cretaceous volcanic-clastic Xiaotian basin.

Fig. 1 

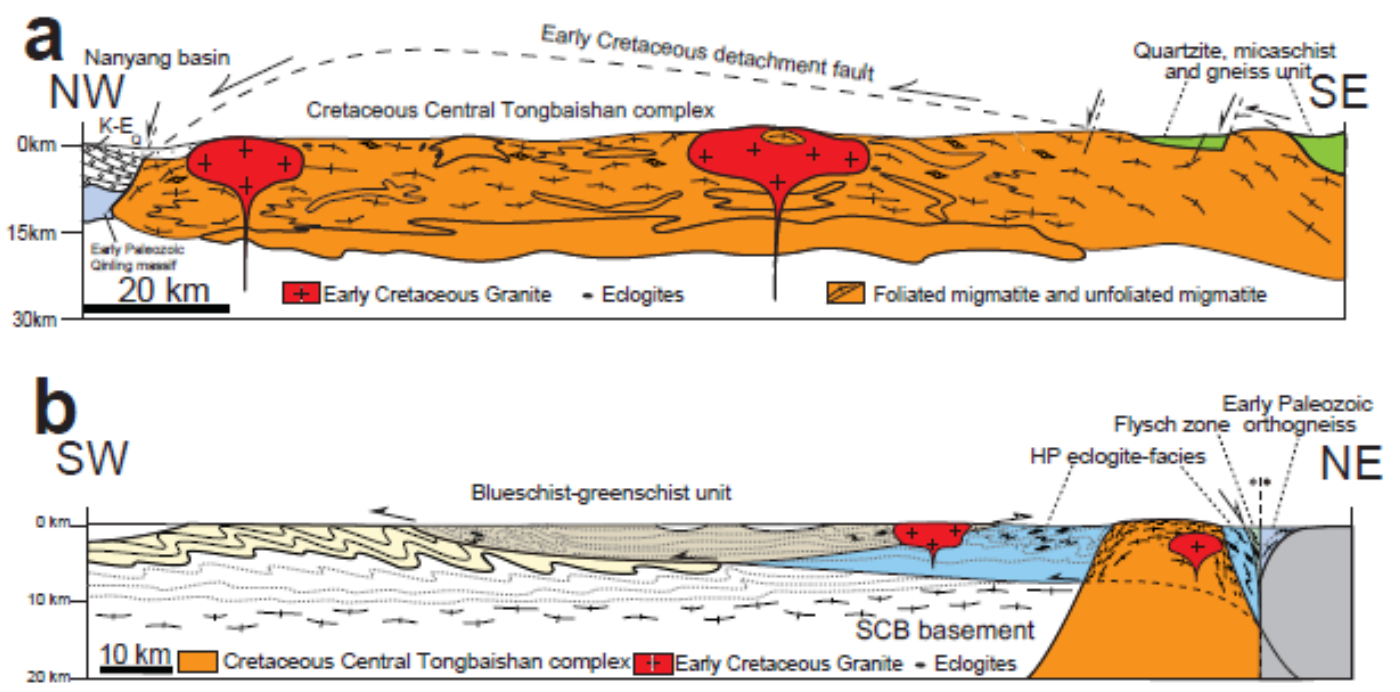

C NW
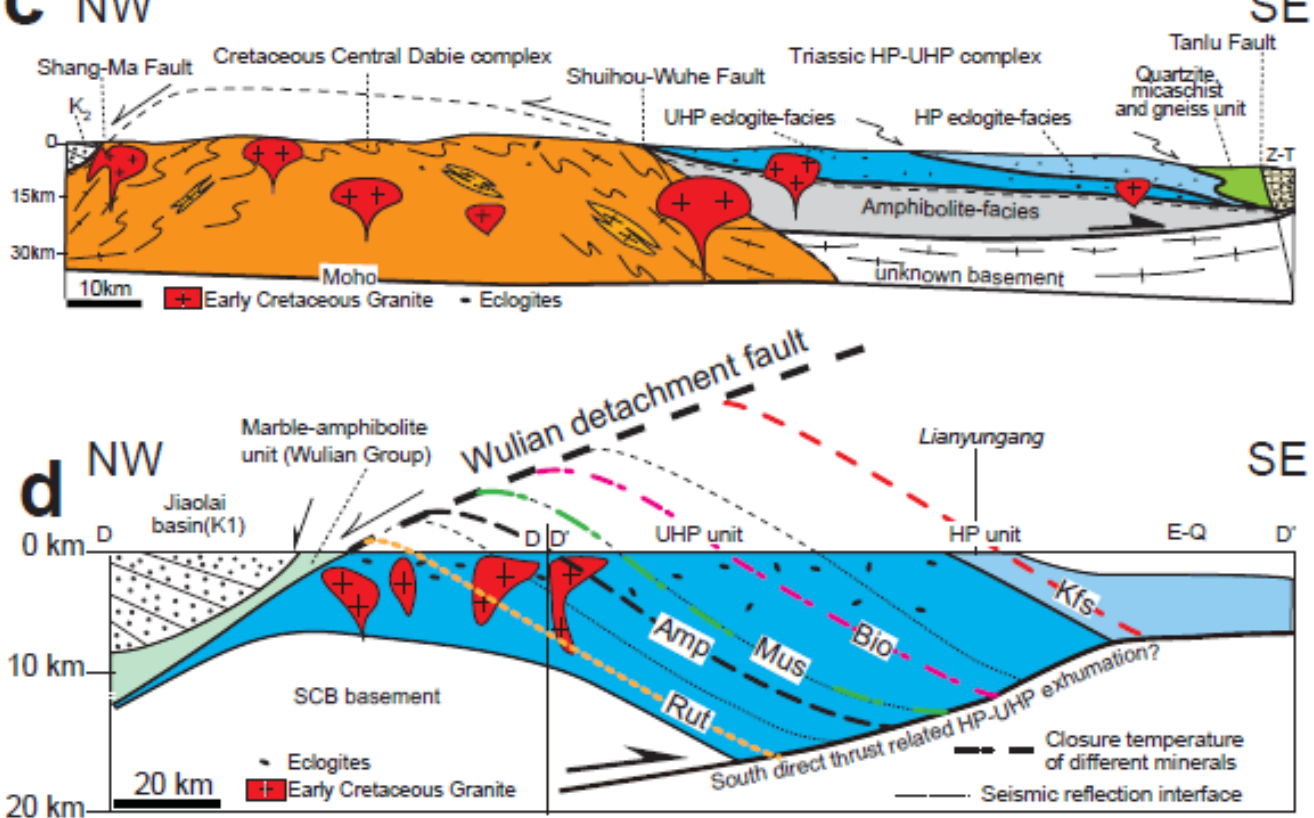

Fig. 2. Schematic cross sections across the central eastern China polystage orogenic belt. $a$ and $b$. Schematic cross section through the Tongbaishan massif with different direction; c. Schematic cross section through the Dabieshan massif (modified from Ji et al., 2011); d. Reinterpreted seismic profile through the southem Sulu massif after Yang et al.(2004). Different dash line show the closure temperature of different minerals in 40Ar-39Ar and U-Pb systems, Rut: rutile; Amp: Amphibole; Mus: Muscovite; Bio: Biotite; and Kfs: K-feldspar. Unnoted symbols and captions in the map are the same as in figure 1. 

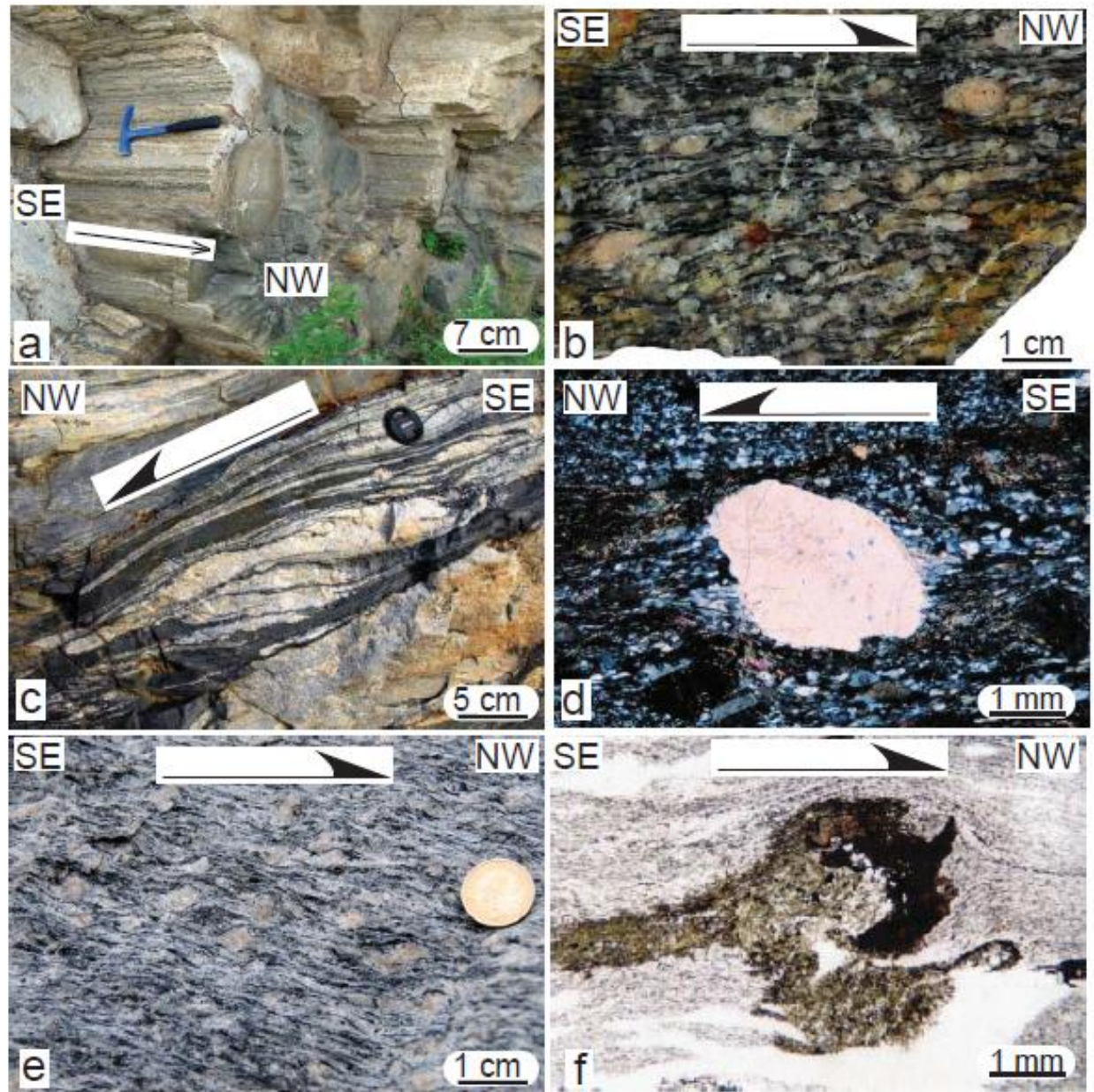

Fig. 3. Field and thin-section (cut parallel to the stretching lineation and perpendicular to the foliation) illustrations of the structures and kinematics related to the Early Cretaceous extensional tectonics. a. L-type tectonites in the central Tongbaishan MCC; b. Top-to-the-NW asymmetric pressure shadow around K-feldspar porphyroblasts and shear band in the central Tongbaishan MCC; c. Asymmetric felsic leucosome in gneissic migmatite indicating a top-to-the-NW shearing in the central Dabieshan MCC; d. Top-to-the-NW asymmetric pressure shadow around a quartz clast in the mylonitic migmatite of Central Dabieshan MCC; e. Sigma-type K-feldspar porphyroclast in ultramylontic orthogneiss, southern Sulu massif; f. Delta-type porphyroclast of zoisite in ultramylontic orthogneiss, southern Sulu massif.

Fig. 3 

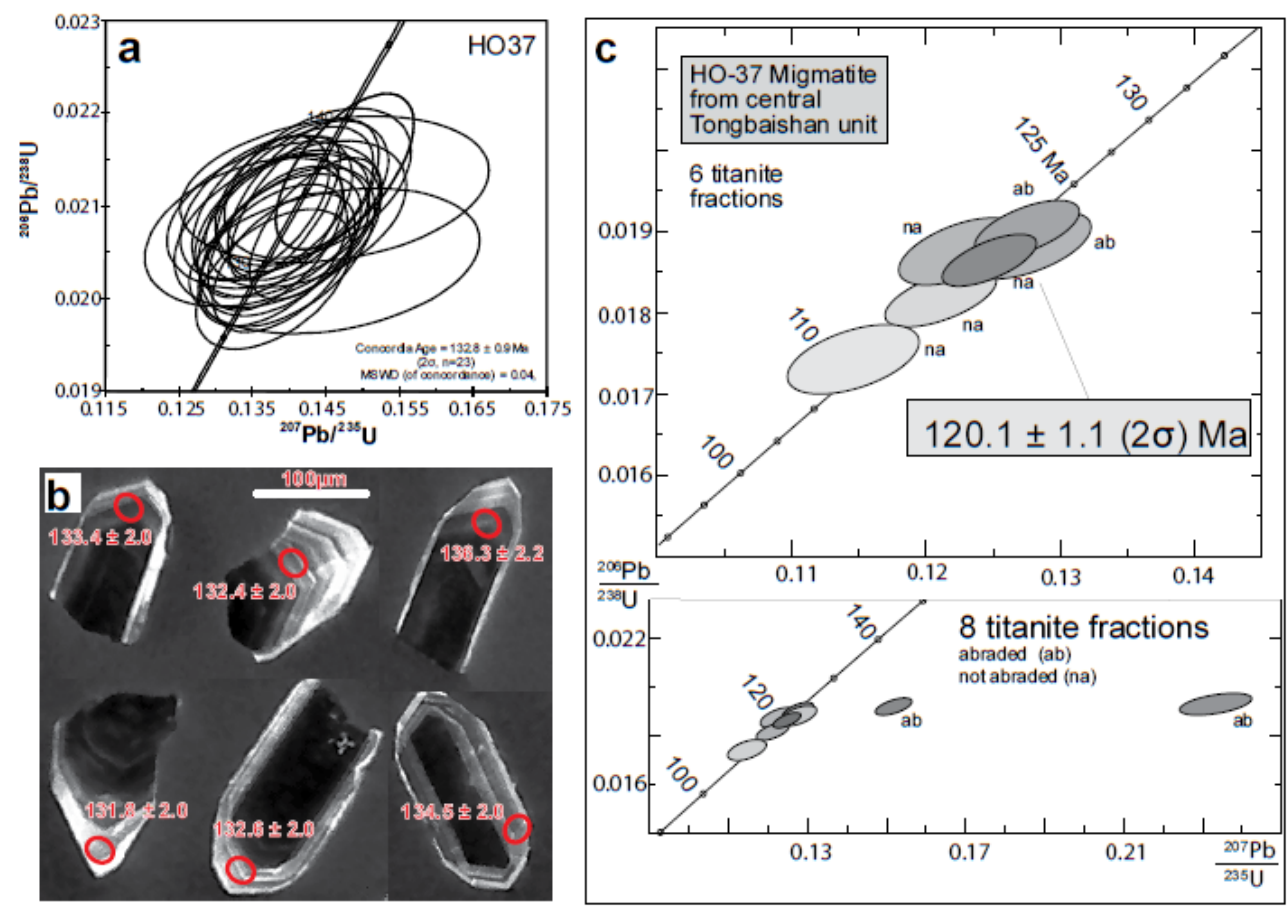

Fig. 4. Geochronological results show the Early Cretaceous extensional tectonics. a and b. zircon SIMS U/Pb dating concordia diagram and cathodomuminescence image with the analysis spots the from the central Tongbaishan MCC; c. U/Pb dating on the titanite from the migmatite of the central Tongbaishan MCC; $d$. 40Ar-39Ar dating on biotite along the south detachment fault of central Dabieshan MCC; e. 40Ar/39Ar dating on muscovite along the Wulian detachment fault of southern Sulu massif, f. SIMS U/Pb dating on the rutile from the Luotian eclogite of the central Dabieshan MCC massif; $\mathrm{g}$. U/Pb dating on the rutile from the Taohang eclogite of the southern Sulu massif.

Fig. 4 

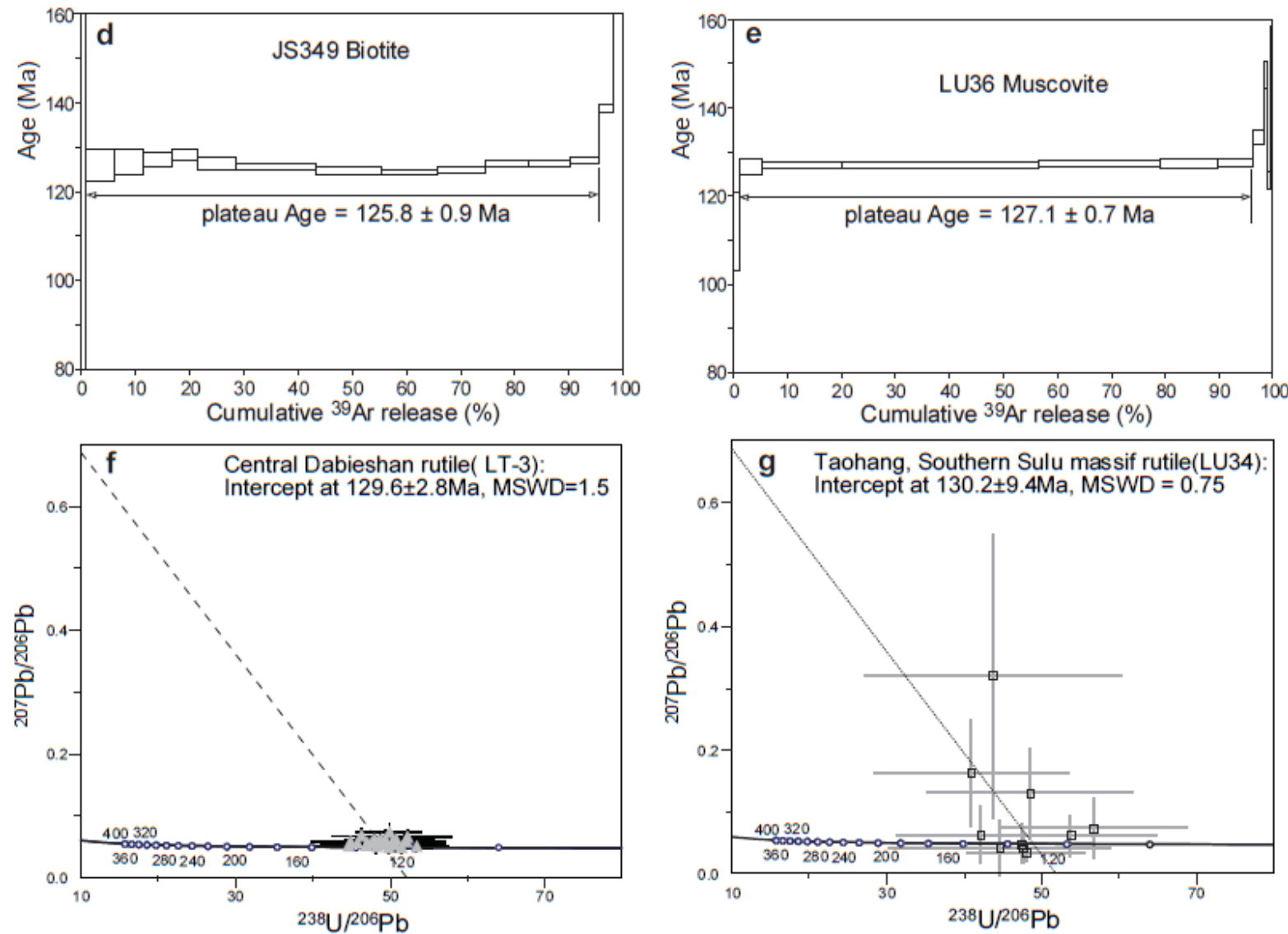

Figure 4 


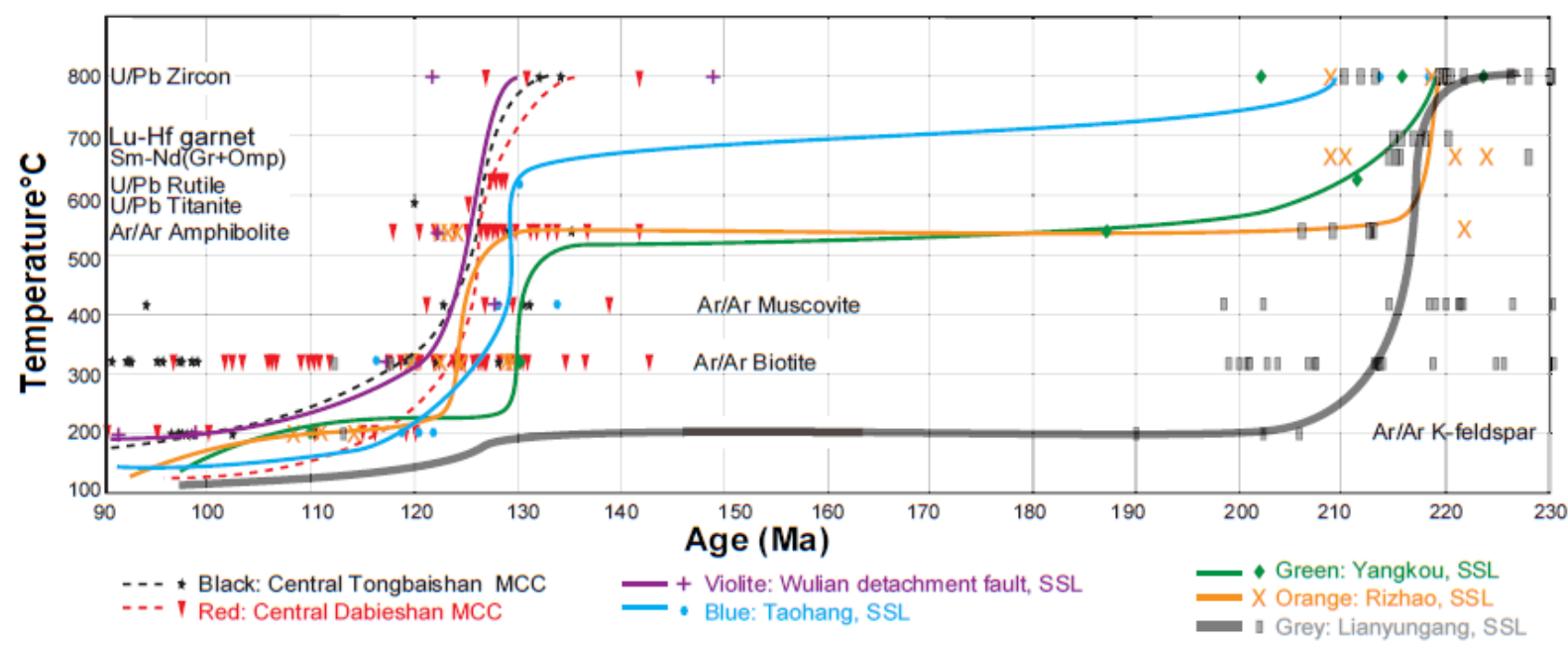

Fig. 5. Cooling paths of the central Tongbaishan A-type non-cylindrical antiform, central Dabieshan MCC, and southern Sulu massifs. The cooling path of southern Sulu massif was separated from NW to SE through the Wulian detachment fault, Taohang, Yangkou, Rizhao and Lianyungang areas. Geochronological results from central Tongbaishan: Xu and Wang, 2010; Cui et al., 2012; Webb et al., 2001; Liu et al., 2012 and our works, central Dabieshan: Ratschbacher et al., 2000; Ji et al., 2011 and references therein and our works, southern Sulu massif. Chen et al., 1992; Faure et al., 2003; Lin et al., 2005; Hacker et al., 2009; Schmidt et al., 2011; Leech and Webb, 2013 and references therein, and this work.

Fig. 5 


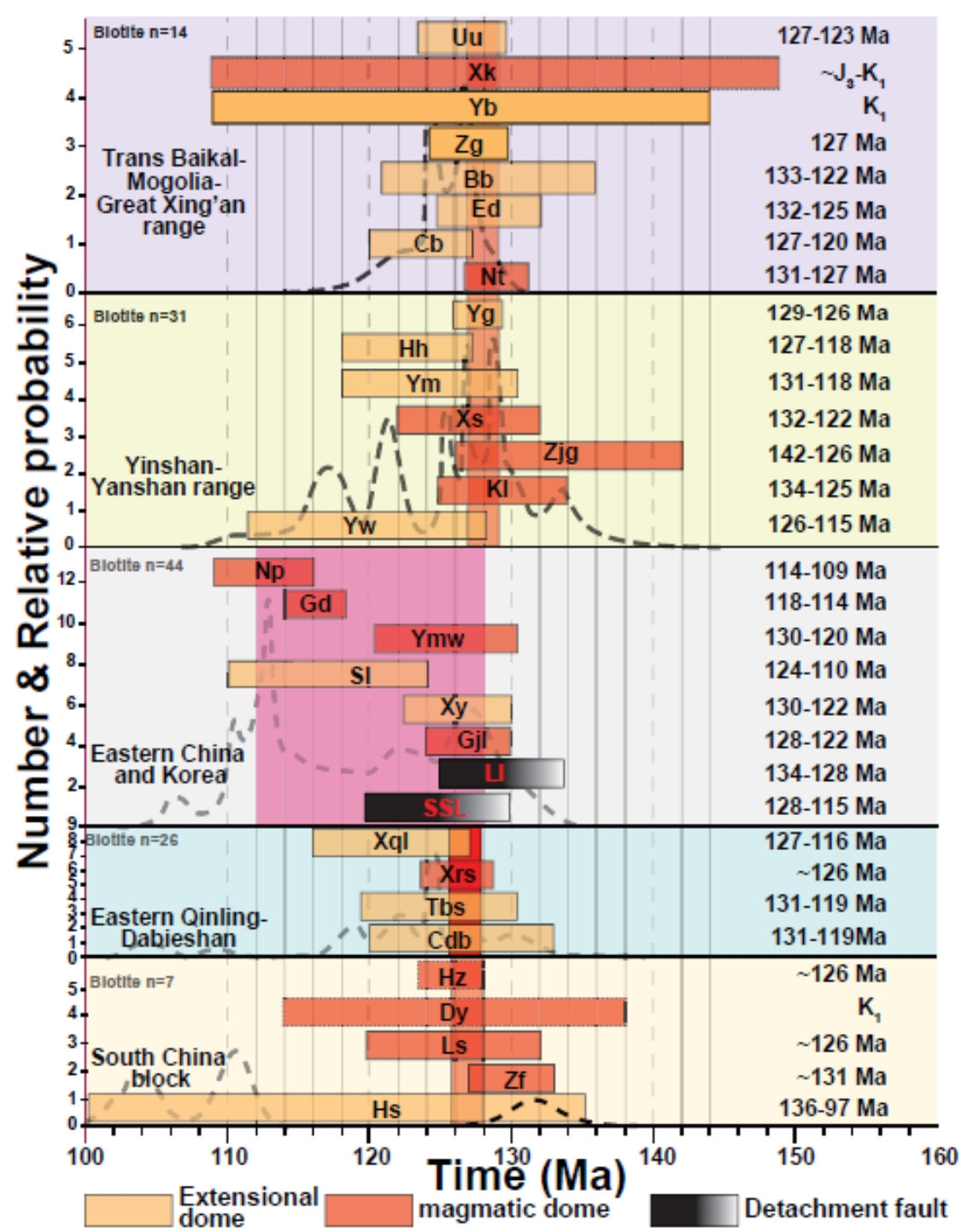

Fig. 6. Extensional structures (extensional dome, magmatic domes and detachment faults) and their radiochronological ages in the eastern part of the Eurasian continent. The dashed line indicates the relative probability of the biotite $40 \mathrm{Ar} / 39 \mathrm{Ar}$ dating on the ductile detachment faults. Abbreviations: Trans Baikal-Mogolia-Great Xing'an range: UU (Ulan-Ude (Selenga) MCC, Mazukabzov et al, 2011. Wang et al .2012) Xk (Xinkailing magmatic đome, Zhao et al., 2007), Yb (Yablonovy MCC Zorin, 1999), Zg (Zagan MCC. Donskaya et al, 2008) Bb (Buteel-Burgutui MCC Mazukabzov et al, 2006; Donskaya et al, 2008); Ed (Ereendavaa MCC Daoudene et al., 2009); Cb (Central basement uplift of Songliao basin MCC, Zhang et al., 2000); Nt (Nartyn magmatic dome, Daoudene et al., 2009): Yinshan-Yanshan rảnge ( $Y$ Y): Yg (Yagan-Onch Hayman MCC Webb et al., 1999), Hh (Hohhot MCC, Davis and Darby, 2010), Ym (Yunmengshan MCC Davis et al., 1996), Xs (Xishan magmatic dome, Wang et al. $2011 \mathrm{~b}$ ), Zijg (Zijingguan magmatic dome, Wang and Li, 2008), Kl' (Kalagin magmatic dome, Han et al., 2001), Yw (Yiwulüshan MCC, Lin et al., 2013); Eastern China and Korea: Np (Nampho magmatic dome, Wu et al. 2007). Gd (Gudaoling magmatic dome, Lin et al., 2011), Ymw (Yimawanshan magmatic dome Lin et al. 2011), SI (South Liaodong Peninsula MCC, Yin and Nie, 1996; Liu et al., 2005; Lin et al. 2008), Xy (Xiuyan MCC, Lin et al., 2011), Gjl (Guojialing magmatic dome, Charles et al., 2011), LI (Linglong detachment fault, Charles et al., 2011), SSL (South Sulu detachment fault, this work); Eastern Qinling-Dabieshan: Xgl (Xiaoginling MCC Zhang et al., 1997); Xrs (Xiongershan magmatic dome, Wang and Zhang, 1999), Tbs (Tongbaishan MCC, this work), Cdb (Central Dabieshan MCC, this work); South China block: Hz (Hongzhen magmatic dome, Zhu et al., 2010), Ls (Lushan magmatic dome, Lin et al., 2000), Dy (Dayunshan syntectonic granite, Our field survey), and Zf (magmatic dome Zhangfang in' Wugongshan massif, Faure et al., 1996). The times of formation of the metamorphic complexes and domes are indicated to reflect the active time of detachment fault. Locations are indicated on figure $1 \mathrm{X}$. 


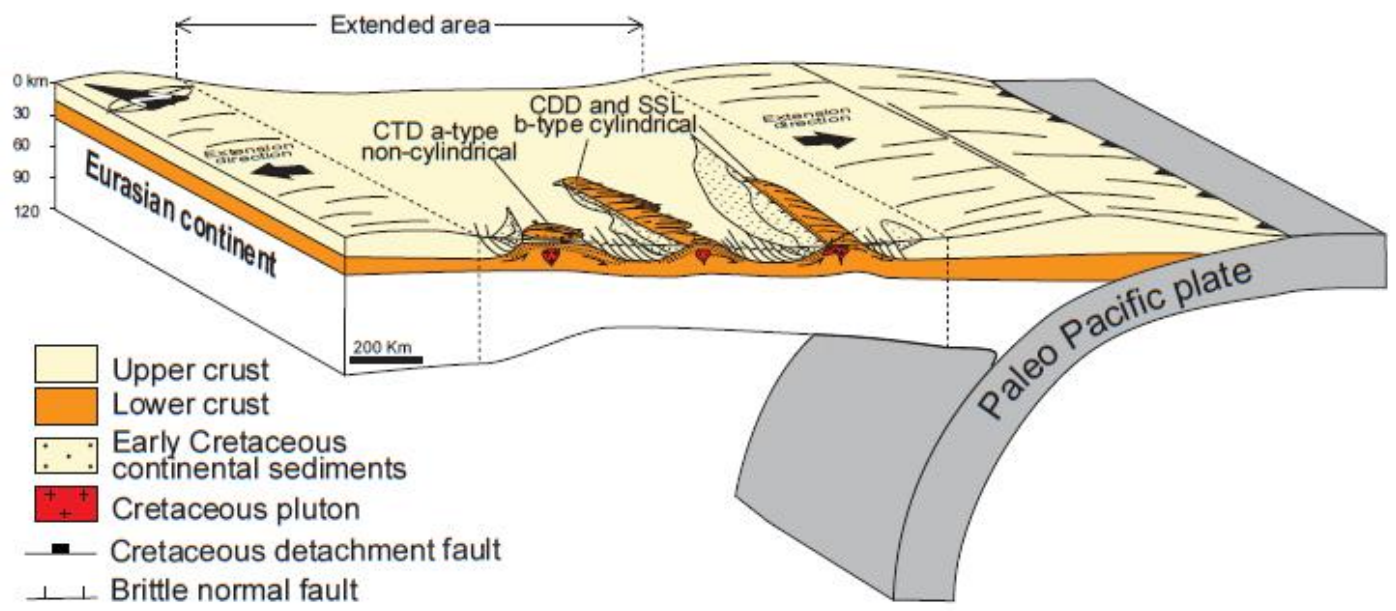

Fig. 7. A 3D conceptual geodynamic model illustrating the different Early Cretaceous extensional structures developed in the Eurasian plate. CTD: central Tongbaishan domain, CDD: central Dabieshan domain, and SSM: southern Sulu massif 
Table 1. SIMS U-Pb analytical results for zircon of the HO37 migmatite from the central Tongbaishan MCC

\begin{tabular}{lcccccccccccccc}
\hline Sample & $\begin{array}{c}\mathrm{U} \\
\text { @spot }\end{array}$ & $\mathrm{ppm}$ & $\mathrm{Tpm}$ & $\mathrm{Th} / \mathrm{U}$ & $\frac{{ }^{207} \mathrm{~Pb}}{{ }^{235} \mathrm{U}}$ & $\begin{array}{c} \pm 1 \sigma \\
(\%)\end{array}$ & $\begin{array}{c}{ }^{206} \mathrm{~Pb} \\
{ }^{238} \mathrm{U}\end{array}$ & $\begin{array}{c} \pm 1 \sigma \\
(\%)\end{array}$ & $\begin{array}{c}\mathrm{t}_{207 / 206} \\
(\mathrm{Ma})\end{array}$ & $\pm 1 \sigma$ & $\begin{array}{c}\mathrm{t}_{206 / 238} \\
(\mathrm{Ma})\end{array}$ & $\begin{array}{c} \pm 1 \sigma \\
\text { HO37, migmatite in the Tongbaishan complex }\end{array}$ & $\begin{array}{c}\mathrm{t}_{207 / 235} \\
(\mathrm{Ma})\end{array}$ & $\pm 1 \sigma$ \\
HO37@1 & 440 & 69 & 0.157 & 0.14076 & 3.10 & 0.0211 & 1.52 & 120.7 & 62.4 & 134.5 & 2.0 & 133.7 & 3.9 \\
HO37@2 & 290 & 35 & 0.122 & 0.14185 & 2.95 & 0.0211 & 1.68 & 139.5 & 56.1 & 134.4 & 2.2 & 134.7 & 3.7 \\
HO37@3 & 396 & 53 & 0.133 & 0.14747 & 2.60 & 0.0214 & 1.60 & 196.8 & 46.7 & 136.3 & 2.2 & 139.7 & 3.4 \\
HO37@4 & 380 & 49 & 0.129 & 0.13729 & 2.91 & 0.0208 & 1.51 & 94.7 & 57.9 & 132.6 & 2.0 & 130.6 & 3.6 \\
HO37@5 & 692 & 70 & 0.101 & 0.13936 & 2.19 & 0.0210 & 1.50 & 108.1 & 37.1 & 133.8 & 2.0 & 132.5 & 2.7 \\
HO37@6 & 530 & 60 & 0.113 & 0.14165 & 3.39 & 0.0211 & 1.51 & 128.2 & 69.9 & 134.9 & 2.0 & 134.5 & 4.3 \\
HO37@7 & 269 & 34 & 0.126 & 0.13771 & 3.01 & 0.0205 & 1.52 & 137.4 & 59.8 & 130.6 & 2.0 & 131.0 & 3.7 \\
HO37@8 & 309 & 42 & 0.135 & 0.13970 & 3.48 & 0.0206 & 1.71 & 161.1 & 69.4 & 131.2 & 2.2 & 132.8 & 4.3 \\
HO37@9 & 161 & 17 & 0.106 & 0.14382 & 3.60 & 0.0212 & 1.55 & 152.2 & 74.4 & 135.5 & 2.1 & 136.4 & 4.6 \\
HO37@10 & 183 & 24 & 0.133 & 0.14219 & 3.93 & 0.0209 & 1.54 & 162.3 & 82.4 & 133.4 & 2.0 & 135.0 & 5.0 \\
HO37@11 & 272 & 37 & 0.138 & 0.13897 & 3.49 & 0.0208 & 1.55 & 119.9 & 72.0 & 132.8 & 2.0 & 132.1 & 4.3 \\
HO37@12 & 235 & 30 & 0.129 & 0.13837 & 4.14 & 0.0207 & 1.64 & 118.5 & 87.2 & 132.3 & 2.1 & 131.6 & 5.1 \\
HO37@13 & 347 & 48 & 0.137 & 0.13683 & 3.49 & 0.0210 & 1.53 & 64.1 & 73.0 & 133.9 & 2.0 & 130.2 & 4.3 \\
HO37@14 & 399 & 53 & 0.132 & 0.14346 & 2.53 & 0.0208 & 1.50 & 200.8 & 46.6 & 132.4 & 2.0 & 136.1 & 3.2 \\
HO37@15 & 198 & 27 & 0.134 & 0.13560 & 4.60 & 0.0207 & 1.58 & 72.5 & 99.6 & 132.2 & 2.1 & 129.1 & 5.6 \\
HO37@16 & 292 & 39 & 0.134 & 0.13923 & 2.84 & 0.0204 & 1.50 & 172.2 & 55.2 & 130.1 & 1.9 & 132.4 & 3.5 \\
HO37@17 & 225 & 28 & 0.125 & 0.13796 & 4.33 & 0.0209 & 1.54 & 92.4 & 93.1 & 133.4 & 2.0 & 131.2 & 5.3 \\
HO37@18 & 289 & 32 & 0.110 & 0.13885 & 3.21 & 0.0206 & 1.52 & 143.9 & 64.9 & 131.4 & 2.0 & 132.0 & 4.0 \\
HO37@19 & 593 & 55 & 0.092 & 0.13604 & 2.80 & 0.0210 & 1.50 & 50.1 & 55.4 & 133.9 & 2.0 & 129.5 & 3.4
\end{tabular}




\begin{tabular}{lccccccccccccc} 
HO37@20 & 338 & 38 & 0.112 & 0.13784 & 3.12 & 0.0202 & 1.52 & 169.5 & 62.5 & 129.0 & 1.9 & 131.1 & 3.9 \\
HO37@21 & 110 & 9 & 0.081 & 0.14611 & 5.52 & 0.0204 & 1.57 & 281.9 & 116.8 & 130.2 & 2.0 & 138.5 & 7.2 \\
HO37@22 & 367 & 34 & 0.094 & 0.13814 & 2.73 & 0.0207 & 1.53 & 124.3 & 52.4 & 131.8 & 2.0 & 131.4 & 3.4 \\
HO37@23 & 145 & 16 & 0.112 & 0.14611 & 5.87 & 0.0212 & 1.52 & 196.3 & 126.6 & 135.1 & 2.0 & 138.5 & 7.6 \\
\hline
\end{tabular}


Table 2. SIMS U-Pb analytical results for rutile of the eclogite

\begin{tabular}{|c|c|c|c|c|c|c|c|}
\hline Sample@spot & $\begin{array}{c}\mathrm{U} \\
\mathrm{ppm}\end{array}$ & $\frac{{ }^{238} \mathrm{U}}{{ }^{206} \mathrm{~Pb}}$ & $\begin{array}{c} \pm 1 \sigma \\
\%\end{array}$ & $\frac{{ }^{207} \mathrm{~Pb}}{{ }^{206} \mathrm{~Pb}}$ & $\begin{array}{c} \pm 1 \sigma \\
\%\end{array}$ & $\begin{array}{c}t_{206 / 238}{ }^{*} \\
(\mathrm{Ma})\end{array}$ & \\
\hline \multicolumn{8}{|c|}{ LT-3, eclogite from Early Cretaceous Central Dabieshan MCC, GPS: N3043.717'; } \\
\hline \multicolumn{8}{|l|}{$\mathrm{E} 115^{\circ} 21.670^{\prime}$} \\
\hline LT-3@1 & 14 & 49.39 & 3.5 & 0.0613 & 12.6 & 127 & 5 \\
\hline LT-3@2 & 21 & 53.46 & 4.0 & 0.0499 & 8.1 & 119 & 5 \\
\hline LT-3@3 & 24 & 50.31 & 3.7 & 0.0574 & 8.5 & 125 & 5 \\
\hline LT-3@4 & 21 & 48.32 & 3.6 & 0.0498 & 9.7 & 132 & 5 \\
\hline LT-3@5 & 15 & 48.50 & 7.6 & 0.0541 & 9.5 & 131 & 10 \\
\hline LT-3@6 & 13 & 50.81 & 5.0 & 0.0608 & 11.1 & 124 & 6 \\
\hline LT-3@7 & 21 & 52.14 & 3.5 & 0.0578 & 8.4 & 121 & 4 \\
\hline LT-3@8 & 21 & 48.43 & 9.0 & 0.0584 & 8.0 & 130 & 12 \\
\hline LT-3@9 & 21 & 50.64 & 3.3 & 0.0534 & 9.9 & 125 & 4 \\
\hline LT-3@10 & 24 & 44.62 & 3.7 & 0.0507 & 7.0 & 143 & 5 \\
\hline LT-3@11 & 20 & 50.38 & 6.3 & 0.0533 & 8.6 & 126 & 8 \\
\hline LT-3@12 & 30 & 47.00 & 7.7 & 0.0515 & 7.4 & 135 & 10 \\
\hline LT-3@13 & 22 & 47.62 & 4.9 & 0.0563 & 8.7 & 133 & 7 \\
\hline LT-3@14 & 16 & 52.25 & 5.6 & 0.0655 & 8.4 & 120 & 7 \\
\hline LT-3@15 & 23 & 51.52 & 4.0 & 0.0482 & 9.5 & 124 & 5 \\
\hline LT-3@16 & 27 & 48.86 & 3.8 & 0.0611 & 7.9 & 129 & 5 \\
\hline LT-3@17 & 24 & 47.96 & 4.0 & 0.0610 & 11.8 & 131 & 5 \\
\hline LT-3@18 & 13 & 46.30 & 4.1 & 0.0675 & 10.2 & 135 & 6 \\
\hline
\end{tabular}




$\begin{array}{llllllll}\text { LT-3@19 } & 14 & 49.83 & 5.1 & 0.0477 & 8.5 & 128 & 6 \\ \text { LT-3@20 } & 20 & 44.87 & 3.5 & 0.0574 & 8.3 & 141 & 5 \\ \text { LT-3@21 } & 31 & 46.88 & 6.6 & 0.0516 & 7.6 & 136 & 9 \\ \text { LT-3@22 } & 19 & 45.77 & 3.7 & 0.0555 & 9.3 & 138 & 5 \\ \text { LT-3@23 } & 20 & 51.99 & 4.2 & 0.0591 & 8.9 & 121 & 5 \\ \text { LT-3@24 } & 12 & 49.94 & 4.2 & 0.0732 & 9.5 & 124 & 5 \\ \text { LT-3@25 } & 17 & 49.58 & 7.8 & 0.0533 & 10.2 & 128 & 10 \\ \text { LT-3@26 } & 19 & 47.05 & 3.8 & 0.0555 & 10.5 & 134 & 5\end{array}$

LU34, eclogite from souther Sulu massif, GPS: N3550.692'; E119³2.381'

\begin{tabular}{lccccccc} 
LU34@1 & 0.32 & 47.67 & 10.0 & 0.0410 & 29.9 & 135 & 14 \\
LU34@3 & 0.38 & 48.53 & 13.7 & 0.1310 & 27.3 & 119 & 17 \\
LU34@5 & 0.17 & 40.89 & 15.3 & 0.1633 & 26.3 & 136 & 22 \\
LU34@6 & 0.59 & 48.06 & 7.9 & 0.0352 & 24.5 & 135 & 11 \\
LU34@8 & 0.32 & 53.79 & 10.4 & 0.0623 & 26.7 & 117 & 12 \\
LU34@10 & 0.20 & 44.61 & 16.1 & 0.0417 & 53.2 & 144 & 23 \\
LU34@14 & 0.11 & 43.71 & 19.1 & 0.3202 & 35.9 & 102 & 28 \\
LU34@15 & 0.50 & 47.50 & 9.6 & 0.0487 & 33.8 & 134 & 13 \\
LU34@17 & 0.36 & 56.79 & 10.7 & 0.0739 & 33.3 & 109 & 12 \\
LU34@18 & 0.17 & 42.11 & 12.9 & 0.0630 & 37.2 & 149 & 20 \\
\hline
\end{tabular}

$\mathrm{t}_{206 / 238^{*}}$ age is calculated by ${ }^{207} \mathrm{~Pb}$-based common-lead correction. 
Table 3. U-Pb analytical results for titanite of the $\mathrm{HO} 37$ migmatite from the central Tongbaishan MCC

\begin{tabular}{|c|c|c|c|c|c|c|c|c|c|c|c|c|c|}
\hline \multirow[t]{2}{*}{ Sample $^{\text {a }}$} & \multirow{2}{*}{ Weight } & \multicolumn{2}{|c|}{ Concentrations $^{b}$} & \multirow{2}{*}{$\frac{{ }^{206} \mathrm{~Pb}}{{ }^{204} \mathrm{~Pb}}$} & \multicolumn{3}{|c|}{ Radiogenic $\mathrm{Pb}$ (atomic \%) ${ }^{\mathrm{d}}$} & \multicolumn{3}{|c|}{ Atomic ratios $^{d}$} & \multicolumn{3}{|c|}{ Apparent ages (Ma) } \\
\hline & & $U$ & $\mathrm{~Pb}_{\mathrm{rad}}$ & & & & & ${ }^{206} \mathrm{~Pb}$ & ${ }^{207} \mathrm{~Pb}$ & ${ }^{207} \mathrm{~Pb}$ & & & \\
\hline Titanite fractions & (mg) & ppm & ppm & $\underset{c}{\text { Measured }}$ & ${ }^{206} \mathrm{~Pb}$ & ${ }^{207} \mathrm{Pr}$ & ${ }^{208} \mathrm{~Pb}$ & ${ }^{238} \mathrm{U}$ & ${ }^{235} \mathrm{U}$ & ${ }^{206} \mathrm{~Pb}$ & $t_{206 / 238}$ & $t_{207 / 235}$ & $t_{207 / 206}$ \\
\hline $\begin{array}{l}\text { (1) } 5 \text { very large euhedral, } \\
\text { transparent grains, not abr. }\end{array}$ & 0.4507 & 68.5 & 1.95 & 38.14 & & 2.8 & 39.8 & 0.01903 & 0.1275 & 0.04860 & 122 & 122 & 128 \\
\hline $\begin{array}{l}\text { (2) } 8 \text { small to medium-size } \\
\text { grains, not abr. }\end{array}$ & 0.2687 & 72.3 & 1.87 & 37.78 & .7 & 2.9 & 36.4 & 0.01818 & 0.1211 & 0.04831 & 116 & 116 & 115 \\
\hline $\begin{array}{l}\text { (4) } 6 \text { medium-size to large } \\
\text { grains, not abr. }\end{array}$ & 0.3271 & 106 & 2.41 & & 65.9 & 3.1 & 31 & 0.01743 & 0.1146 & 0.04769 & 111 & 110 & 84.1 \\
\hline $\begin{array}{l}\text { (5) } 20 \text { small euhedral, } \\
\text { transparent grains, abr. }\end{array}$ & 0.12 & 385 & 10.4 & 42.4 & 59.8 & 2.9 & 37.3 & 0.01864 & 0.1247 & 0.04852 & 119 & 119 & 125 \\
\hline $\begin{array}{l}\text { (8) } 4 \text { large euhedral grains, } \\
\text { abr. }\end{array}$ & 0.1256 & 61.4 & 1.83 & 35.64 & 55.8 & 4.9 & 39.3 & 0.01931 & 0.2333 & 0.08765 & 123 & 213 & 1374 \\
\hline
\end{tabular}


a All grains analyzed were individually selected after habit and quality. Most grains were yellow-brown, euhedral and transparent. Mechanical abrasion was perfomed according to Krogh (1982) with pyrite for $1 / 2 \mathrm{~h}$ at $0.5 \mathrm{~atm}$ over-pressure. abr. = abraded; not abr. = not abraded. Very large grains: $>0.20 \mathrm{~mm} ;$ large grains: $0.15-0.20 \mathrm{~mm}$; medium-size grains: $0.10-0.15 \mathrm{~mm}$; small grains: $<0.1 \mathrm{~mm}$. Grain description necessarily applies to characteristics prior to abrasion. b Corrected for (1) mass-discrimination, (2) isotopic tracer contribution, (3) Pb blank [ $30 \mathrm{pg}$ for fractions $<0.3 \mathrm{mg}, 150 \mathrm{pg}$ for fractions $>0.3 \mathrm{mg}$, due to difference in chemical procedure], (4) $1 \mathrm{pg}$ of $\mathrm{U}$ blank for all fractions, and (5) initial $\mathrm{Pb}$, as deduced from the Stacey and $\mathrm{Kramer}^{1}$ model for $\mathrm{Pb}$ isotope evolution of average continental crust.

c Corrected for mass-discrimination and isotopic tracer contribution.

d Ratios corrected for mass-discrimination, isotopic tracer contribution, $\mathrm{Pb}$ and $\mathrm{U}$ blank, and initial common $\mathrm{Pb}$.

e Decay constants used were determined by Jaffey et al. (1971), recommended by IGC (Steiger and Jäger, 1977). 
Table $4 .{ }^{40} \mathrm{Ar} /{ }^{39} \mathrm{Ar}$ analytical results from detachment fault

\begin{tabular}{|c|c|c|c|c|c|c|c|c|c|c|c|c|}
\hline Temperature $\left(^{\circ}\right.$ & ${ }^{40} \mathrm{Ar} / 39$ & & ${ }^{37} \mathrm{Ar} / 39$ & & ${ }^{36} \mathrm{Ar} / 39$ & & P & & ${ }^{40} \mathrm{Ar}^{*}$ & ${ }^{39} \mathrm{Ar}_{\mathrm{K}}$ & Age & $\pm 2 \sigma$ \\
\hline
\end{tabular}

JS349, mylonitic gneiss from Central Dabieshan MCC, GPS: N30³2.126'; E115¹0.050'

Biotite, $\mathrm{J}=0.004822 \pm$

0.000012

\begin{tabular}{|c|c|c|c|c|c|c|c|c|c|c|c|c|}
\hline \multirow{3}{*}{750} & 102.33 & 0.655 & 0.0304 & 0.0057 & 0.2969 & 0.0189 & \multirow{3}{*}{14.5954} & 4.306 & \multirow{3}{*}{14.26} & \multirow{3}{*}{0.85} & \multirow{3}{*}{122.99} & \multirow{3}{*}{ \pm 70.17} \\
\hline & & & & & & & & & & & & \\
\hline & 6 & 5 & 7 & & 3 & 4 & & 9 & & & & \\
\hline \multirow{3}{*}{800} & 40.053 & 0.008 & 0.0070 & 0.0000 & 0.0848 & 0.0004 & \multirow{3}{*}{14.9700} & 0.242 & \multirow{3}{*}{37.37} & \multirow{3}{*}{5.32} & \multirow{3}{*}{126.04} & \multirow{3}{*}{ \pm 3.95} \\
\hline & & & & & & & & & & & & \\
\hline & 9 & 6 & 6 & 8 & 9 & 9 & & 9 & & & & \\
\hline 840 & 36.090 & 0.009 & 0.0023 & 0.0003 & 0.0712 & 0.0002 & 15.0333 & 0.182 & 41.65 & 5.27 & 126.55 & \pm 2.96 \\
\hline
\end{tabular}




\begin{tabular}{|c|c|c|c|c|c|c|c|c|c|c|c|c|}
\hline & 4 & 6 & 6 & 3 & 6 & 5 & & 1 & & & & \\
\hline \multirow{3}{*}{880} & 25.539 & 0.004 & 0.0102 & 0.0001 & 0.0351 & 0.0001 & & 0.097 & \multirow{3}{*}{59.32} & \multirow{3}{*}{5.21} & \multirow{3}{*}{127.50} & \multirow{3}{*}{ \pm 1.58} \\
\hline & & & & & & & 15.1496 & & & & & \\
\hline & 6 & 8 & 9 & 5 & 6 & 2 & & 1 & & & & \\
\hline \multirow{3}{*}{920} & 22.313 & 0.004 & & 0.0003 & 0.0238 & 0.0001 & & 0.083 & \multirow{3}{*}{68.44} & \multirow{3}{*}{4.92} & \multirow{3}{*}{128.50} & \multirow{3}{*}{ \pm 1.35} \\
\hline & & & 0.001 & & & $\Delta$ & 15.2725 & & & & & \\
\hline & 7 & 0 & & 1 & 3 & 1 & & 0 & & & & \\
\hline \multirow{3}{*}{960} & 23.426 & 0.008 & 0.0243 & 0.0002 & 0.0285 & 0.0001 & & 0.084 & \multirow{3}{*}{64.01} & \multirow{3}{*}{7.09} & \multirow{3}{*}{126.25} & \multirow{3}{*}{ \pm 1.38} \\
\hline & & & & & & & 14.9962 & & & & & \\
\hline & 2 & 5 & 4 & 0 & & 2 & & 8 & & & & \\
\hline \multirow{3}{*}{1000} & 19.733 & 0.011 & 0.0113 & 0.0000 & 0.0162 & 0.0000 & \multirow{3}{*}{14.9193} & 0.055 & \multirow{3}{*}{75.6} & \multirow{3}{*}{14.61} & \multirow{3}{*}{125.63} & \multirow{3}{*}{ \pm 0.91} \\
\hline & & & & & & & & & & & & \\
\hline & 2 & 6 & 2 & 9 & 9 & 6 & & 8 & & & & \\
\hline \multirow{3}{*}{1020} & 17.454 & 0.005 & 0.0082 & 0.0001 & 0.0089 & 0.0000 & \multirow{3}{*}{14.8025} & 0.046 & \multirow{3}{*}{84.81} & \multirow{3}{*}{12.11} & \multirow{3}{*}{124.67} & \multirow{3}{*}{ \pm 0.75} \\
\hline & & & & & & & & & & & & \\
\hline & 5 & 7 & 7 & 2 & 8 & 4 & & 3 & & & & \\
\hline 1040 & 16.481 & 0.002 & 0.0113 & 0.0001 & 0.0057 & 0.0000 & 14.7711 & 0.036 & 89.62 & 10.35 & 124.42 & \pm 0.59 \\
\hline
\end{tabular}




\begin{tabular}{|c|c|c|c|c|c|c|c|c|c|c|c|c|c|}
\hline & 2 & 6 & 1 & 8 & 9 & 2 & & 3 & & & & & \\
\hline \multirow{3}{*}{1060} & 16.320 & 0.003 & 0.0107 & 0.0001 & 0.0050 & 0.0000 & & 0.040 & \multirow{3}{*}{90.9} & \multirow{3}{*}{8.78} & \multirow{3}{*}{124.94} & \multirow{3}{*}{ \pm} & \\
\hline & & & & & & & 14.8348 & & & & & & 0.66 \\
\hline & 3 & 8 & 5 & 5 & 3 & 3 & & 3 & & & & & \\
\hline \multirow{3}{*}{1080} & 16.286 & 0.004 & 0.0195 & 0.0001 & 0.0042 & 0.0000 & & 0.038 & \multirow{3}{*}{92.33} & \multirow{3}{*}{8.12} & \multirow{3}{*}{126.59} & \multirow{3}{*}{ \pm} & \multirow{3}{*}{0.62} \\
\hline & & & & & & 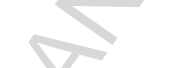 & 15.0377 & & & & & & \\
\hline & 9 & 1 & 8 & 3 & 3 & 3 & & 1 & & & & & \\
\hline \multirow{3}{*}{1100} & 15.873 & 0.003 & 0.0024 & 0.0001 & 0.0029 & 0.0000 & & 0.035 & \multirow{3}{*}{94.5} & \multirow{3}{*}{7.56} & \multirow{3}{*}{126.28} & \multirow{3}{*}{ \pm} & \multirow{3}{*}{0.57} \\
\hline & & & & & & & 15.0001 & & & & & & \\
\hline & 9 & 4 & 6 & 0 & & 1 & & 3 & & & & & \\
\hline \multirow{3}{*}{1120} & 15.864 & 0.002 & 0.0050 & 0.0001 & 0.0026 & 0.0000 & \multirow{3}{*}{15.0933} & 0.041 & \multirow{3}{*}{95.14} & \multirow{3}{*}{5.43} & \multirow{3}{*}{127.04} & \multirow{3}{*}{ \pm} & \multirow{3}{*}{.68} \\
\hline & & & & & & & & & & & & & \\
\hline & 7 & 4 & 3 & 0 & 1 & 2 & & 8 & & & & & \\
\hline \multirow{3}{*}{1150} & 17.298 & 0.001 & 0.0212 & 0.0002 & 0.0026 & 0.0000 & \multirow{3}{*}{16.5151} & 0.057 & \multirow{3}{*}{95.47} & \multirow{3}{*}{2.44} & \multirow{3}{*}{138.56} & \multirow{3}{*}{ \pm} & \multirow{3}{*}{0.93} \\
\hline & & & & & & & & & & & & & \\
\hline & 7 & 4 & 3 & 9 & 6 & 2 & & 6 & & & & & \\
\hline 1250 & 34.093 & 0.004 & 0.0437 & 0.0006 & 0.0073 & 0.0000 & 31.9140 & 0.085 & 93.6 & 1.67 & 258.84 & \pm & 1.30 \\
\hline
\end{tabular}




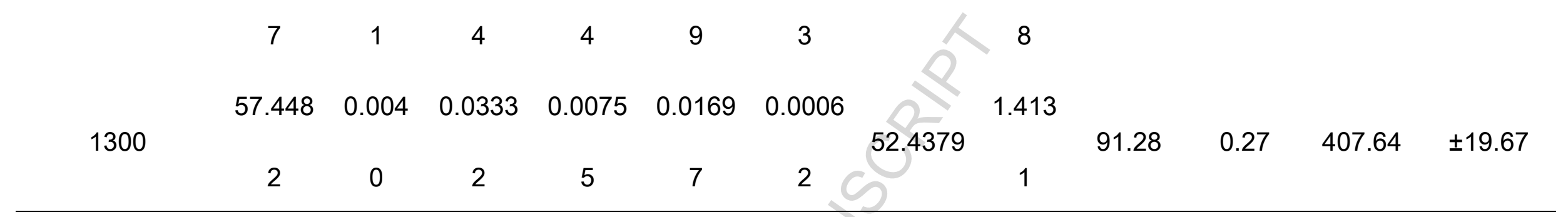

LU36, mylonitic orthogneiss from Sulu massif, GPS: N3550.014'; E119 $32.044^{\prime}$

Muscovite, $\mathrm{J}=0.00344700 \pm 0.00000862$

\begin{tabular}{|c|c|c|c|c|c|c|c|c|c|c|c|c|}
\hline \multirow{3}{*}{750} & 30.693 & 1.222 & 0.0205 & 0.0038 & 0.0411 & 0.0017 & \multirow{3}{*}{18.5443} & 0.750 & \multirow{3}{*}{60.42} & \multirow{3}{*}{0.99} & \multirow{3}{*}{112.05} & \multirow{3}{*}{ \pm 8.80} \\
\hline & & & & & & & & & & & & \\
\hline & 8 & 3 & 8 & 9 & & 0 & & 8 & & & & \\
\hline \multirow{3}{*}{800} & 22.908 & 0.160 & 0.0015 & 0.0004 & 0.0062 & 0.0001 & \multirow{3}{*}{21.0593} & 0.152 & \multirow{3}{*}{91.93} & \multirow{3}{*}{4.3} & \multirow{3}{*}{126.72} & \multirow{3}{*}{ \pm 1.77} \\
\hline & & & & & & & & & & & & \\
\hline & 8 & 7 & 5 & & 6 & 2 & & 0 & & & & \\
\hline \multirow{3}{*}{850} & 22.002 & 0.066 & 0.0004 & 0.0001 & 0.0031 & 0.0000 & \multirow{3}{*}{21.0837} & 0.064 & \multirow{3}{*}{95.83} & \multirow{3}{*}{14.68} & \multirow{3}{*}{126.86} & \multirow{3}{*}{ \pm 0.75} \\
\hline & & & & & & & & & & & & \\
\hline & 1 & 1 & 2 & 5 & 1 & 3 & & 3 & & & & \\
\hline 890 & 21.491 & 0.051 & 0.0000 & 0.0000 & 0.0013 & 0.0000 & 21.0968 & 0.050 & 98.16 & 36.51 & 126.94 & \pm 0.58 \\
\hline
\end{tabular}




\begin{tabular}{|c|c|c|c|c|c|c|c|c|c|c|c|c|}
\hline & 6 & 0 & 6 & 8 & 4 & 2 & & 3 & & & & \\
\hline \multirow{3}{*}{920} & 21.531 & 0.063 & 0.0001 & 0.0001 & 0.0012 & 0.0000 & & 0.062 & \multirow{3}{*}{98.26} & \multirow{3}{*}{22.55} & \multirow{3}{*}{127.29} & \multirow{3}{*}{ \pm 0.72} \\
\hline & & & & & & & 21.1562 & & & & & \\
\hline & 8 & 0 & 7 & 1 & 7 & 2 & & 2 & & & & \\
\hline \multirow{3}{*}{950} & 21.856 & 0.092 & 0.0017 & 0.0001 & 0.0023 & 0.0000 & & 0.090 & \multirow{3}{*}{96.81} & \multirow{3}{*}{10.82} & \multirow{3}{*}{127.31} & \multirow{3}{*}{ \pm 1.05} \\
\hline & & & & & & $x$ & 21.1602 & & & & & \\
\hline & 5 & 6 & 4 & 4 & 6 & & & 1 & & & & \\
\hline \multirow{3}{*}{990} & 22.283 & 0.081 & 0.0005 & 0.0002 & 0.0036 & 0.0000 & & 0.079 & \multirow{3}{*}{95.13} & \multirow{3}{*}{6.35} & \multirow{3}{*}{127.53} & \multirow{3}{*}{$\pm \quad 0.92$} \\
\hline & & & & & & & 21.1978 & & & & & \\
\hline & 7 & 8 & 0 & 2 & & 5 & & 4 & & & & \\
\hline \multirow{3}{*}{1030} & 23.669 & 0.152 & 0.0034 & 0.0010 & 0.0050 & 0.0000 & \multirow{3}{*}{22.1922} & 0.144 & \multirow{3}{*}{93.76} & \multirow{3}{*}{2.03} & \multirow{3}{*}{133.29} & \multirow{3}{*}{ \pm 1.67} \\
\hline & & & & & & & & & & & & \\
\hline & 6 & 0 & 8 & 1 & 0 & 8 & & 4 & & & & \\
\hline \multirow{3}{*}{1080} & 26.526 & 0.275 & 0.0142 & 0.0040 & 0.0063 & 0.0002 & \multirow{3}{*}{24.6588} & 0.266 & \multirow{3}{*}{92.96} & \multirow{3}{*}{0.65} & \multirow{3}{*}{147.52} & \multirow{3}{*}{ \pm 3.06} \\
\hline & & & & & & & & & & & & \\
\hline & 5 & 6 & 7 & 9 & 3 & 5 & & 4 & & & & \\
\hline 1180 & 23.551 & 0.174 & 0.0051 & 0.0024 & 0.0102 & 0.0002 & 20.5212 & 0.167 & 87.13 & 0.74 & 123.59 & \pm 1.95 \\
\hline
\end{tabular}




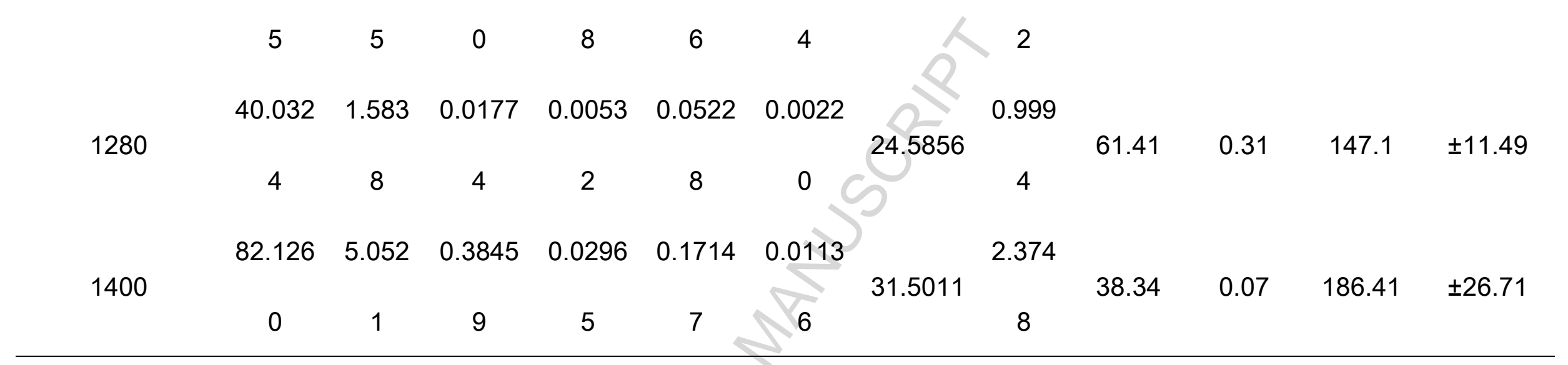




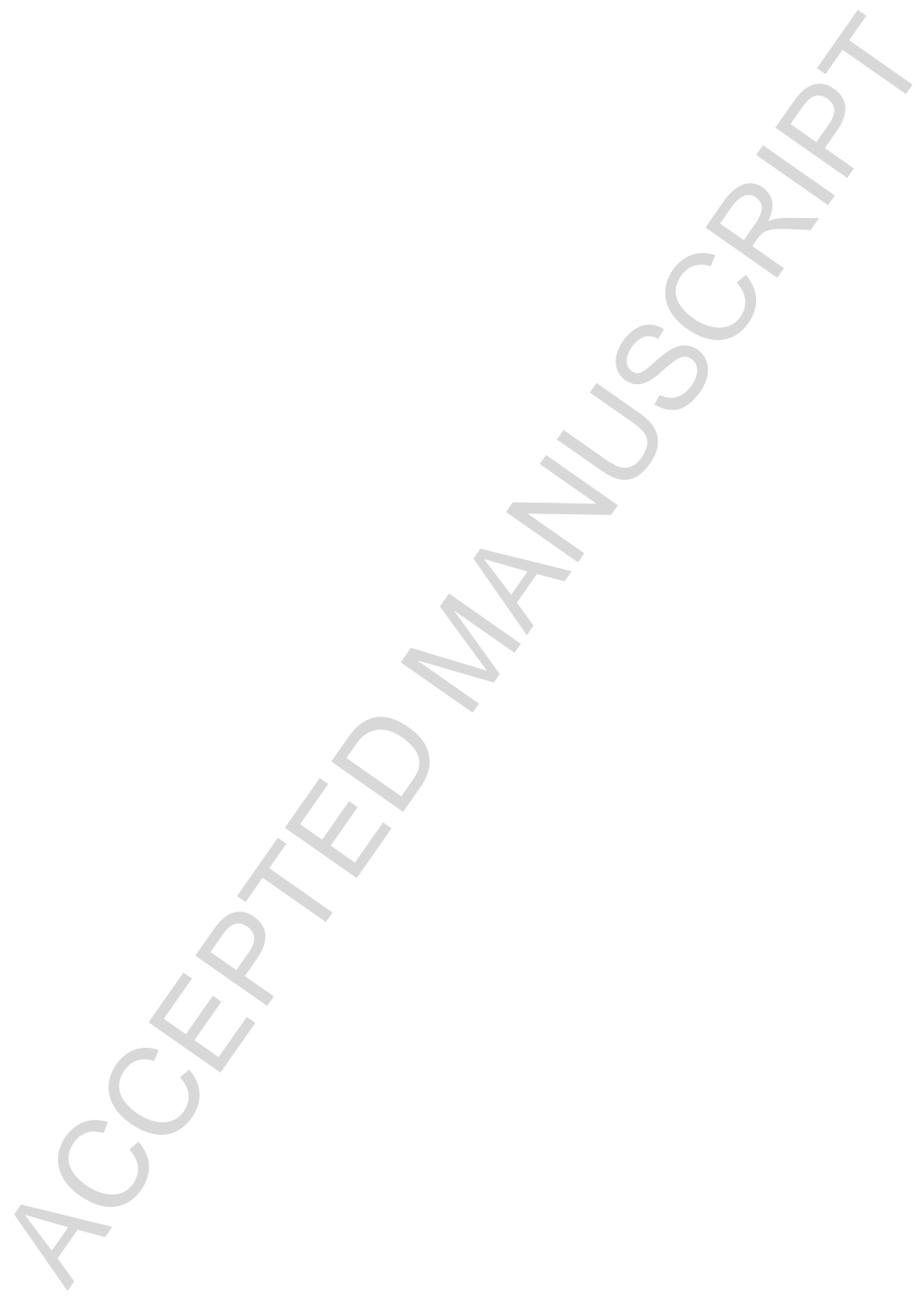




\section{Highlights}

HP-UHP massifs are corresponding to the Triassic collision between NCB and SCB

More than 50\% of the HP-UHP massifs reworked by Cretaceous extensional tectonics

Each individual segment documents different Early Cretaceous extensional structures

The mechanism of extensional tectonics has no relationship with HP-UHP orogen 